\title{
Biotic and environmental changes in the Panthalassa Ocean across the Norian (Late Triassic) impact event
}

Honami Sato ${ }^{1,2^{*}}$ D, Yutaro Takaya ${ }^{1,2,3,4}$, Kazutaka Yasukawa ${ }^{1,4,5}$, Koichiro Fujinaga ${ }^{1,4}$, Tetsuji Onoue and $^{6}$ Yasuhiro Kato $1,2,4,5$

\begin{abstract}
Stratigraphic records of impact ejecta preserved in a pelagic deep-sea setting occur within Upper Triassic successions of the subduction-generated accretionary complexes of central Japan. A significant biotic turnover in radiolarians occurred during the $\sim 300 \mathrm{kyr}$ time interval after the impact event, which is characterized by a remarkable reduction in the burial flux of radiolarian silica. However, the nature of the environmental conditions at this time remains unclear. To investigate the environmental changes that triggered a decline in radiolarian burial flux after the impact event, geochemical proxies (major, trace, and rare earth elements) were applied to the middle-upper Norian (Upper Triassic) bedded chert succession of the Mino Belt, central Japan. A progressive environmental deterioration is evident from (1) a post-impact shutdown of burial flux of primary and silica- and apatite-secreting organisms; and (2) a subsequent abrupt increase in chemical weathering associated with a sustained reduction in the burial flux of radiolarian silica. No significant redox changes were observed across the impact event. The continental weathering proxies suggest a transient increase in weathering intensity occurred during the decline of radiolarian burial flux, likely in response to a short-term warm and humid period. Our results delineate a remarkable record of progressive environmental changes in the Panthalassa Ocean after this large impact event.
\end{abstract}

Keywords: Late Triassic, Norian, Bedded chert, Impact event, Environmental changes, Radiolaria

\section{Introduction}

An Upper Triassic (Norian) impact event has been inferred from anomalous concentrations of platinumgroup elements (PGEs) and a negative osmium (Os) isotope excursion, in addition to occurrences of microspherules and Ni-rich magnetite, in a claystone layer in an Upper Triassic bedded chert succession in the Sakahogi section, central Japan (Onoue et al. 2012; Sato et al. 2013; Sato et al. 2016) (Fig. 1). Previous paleomagnetic

\footnotetext{
* Correspondence: honami.sato@p.chibakoudai.jp

'Ocean Resources Research Center for Next Generation, Chiba Institute of

Technology, 2-17-1 Tsudanuma, Narashino, Chiba 275-0016, Japan

${ }^{2}$ Submarine Resources Research Center, Research Institute for Marine Resources Utilization, Japan Agency for Marine-Earth Science and

Technology, 2-15 Natsushima-cho, Yokosuka, Kanagawa 237-0061, Japan

Full list of author information is available at the end of the article
}

studies of the Triassic bedded chert succession in the Sakahogi section suggest that these sediments accumulated in a pelagic, open-ocean setting within a low- to mid-latitudinal zone of the Panthalassa Ocean (Uno et al. 2015) (Fig. 2). The late middle Norian age of the claystone layer (Onoue et al. 2016a; Yamashita et al. 2018) suggests that the PGE anomalies originate from an extraterrestrial source, related to an impact event that formed the $90 \mathrm{~km}$-diameter Manicouagan crater in Canada at 215.5 Ma (Clutson et al. 2018) (Fig. 2). Studies of PGEs and Os isotopes have revealed that the anomalously high PGE abundances in the lower sublayer claystone resulted from a large chondritic impactor with a diameter of 3.3-7.8 km (Sato et al. 2013; Sato et al. 2016).
Springer Open (c) The Author(s). 2020 Open Access This article is licensed under a Creative Commons Attribution 4.0 International License, which permits use, sharing, adaptation, distribution and reproduction in any medium or format, as long as you give appropriate credit to the original author(s) and the source, provide a link to the Creative Commons licence, and indicate if changes were made. The images or other third party material in this article are included in the article's Creative Commons licence, unless indicated otherwise in a credit line to the material. If material is not included in the article's Creative Commons licence and your intended use is not permitted by statutory regulation or exceeds the permitted use, you will need to obtain permission directly from the copyright holder. To view a copy of this licence, visit http://creativecommons.org/licenses/by/4.0/. 


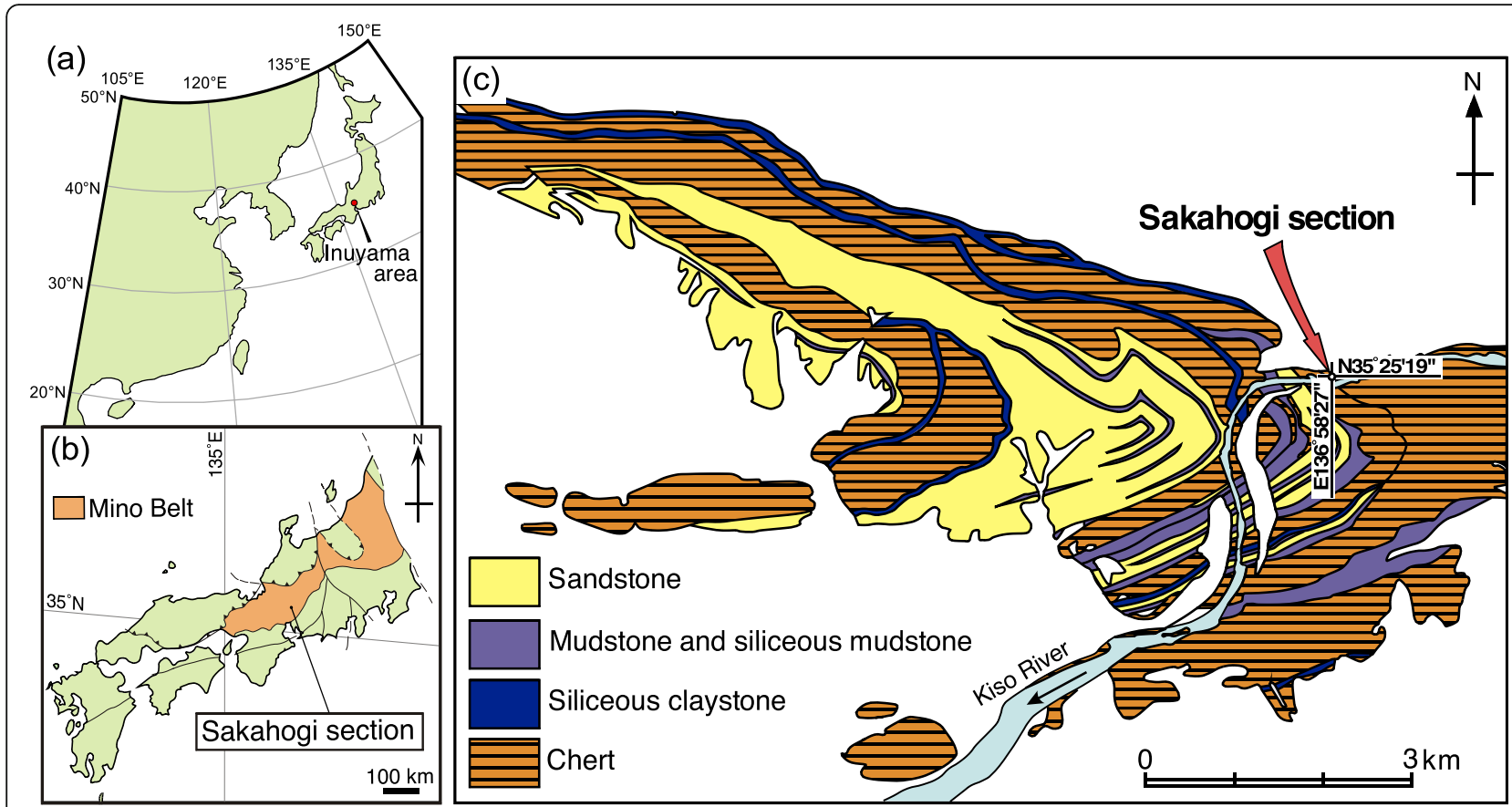

Fig. 1 Map showing the study area. a, b Geographic maps of the study area in the Inuyama area, Mino Belt, central Japan. c The Sakahogi section along the middle reaches of Kiso River

Onoue et al. (2016a) showed that extinctions of middle Norian radiolarian species occurred in a stepwise fashion in the $\sim 1$ Myr interval above the ejecta horizon, which was associated with the radiation of late Norian radiolarians (Fig. 3a). Furthermore, high-resolution paleontological and geochemical data also revealed that two paleoenvironmental events occurred during the initial phase of the radiolarian turnover interval. The first event (E1) involved post-impact shutdown of primary productivity reflected by a remarkable decline in the

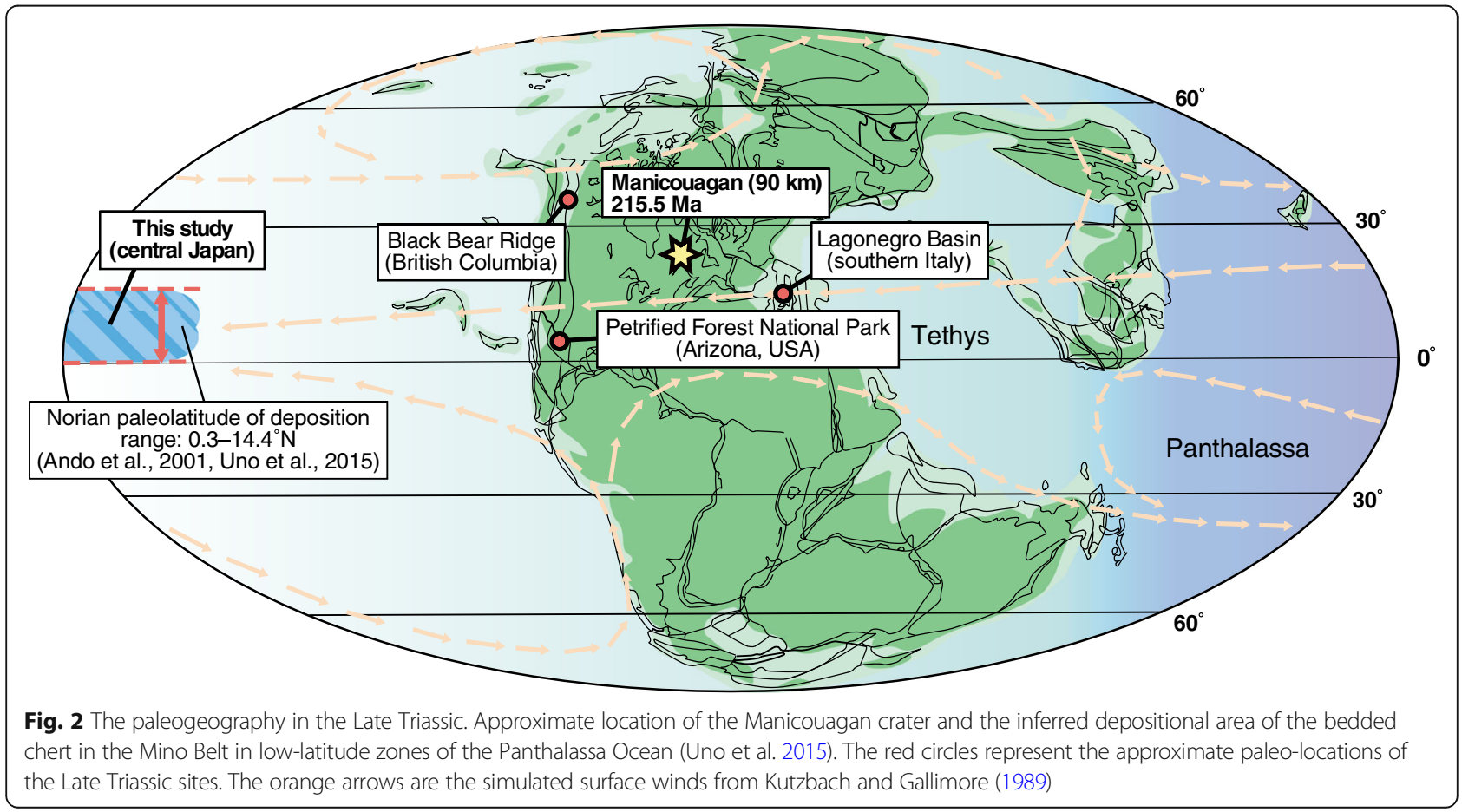




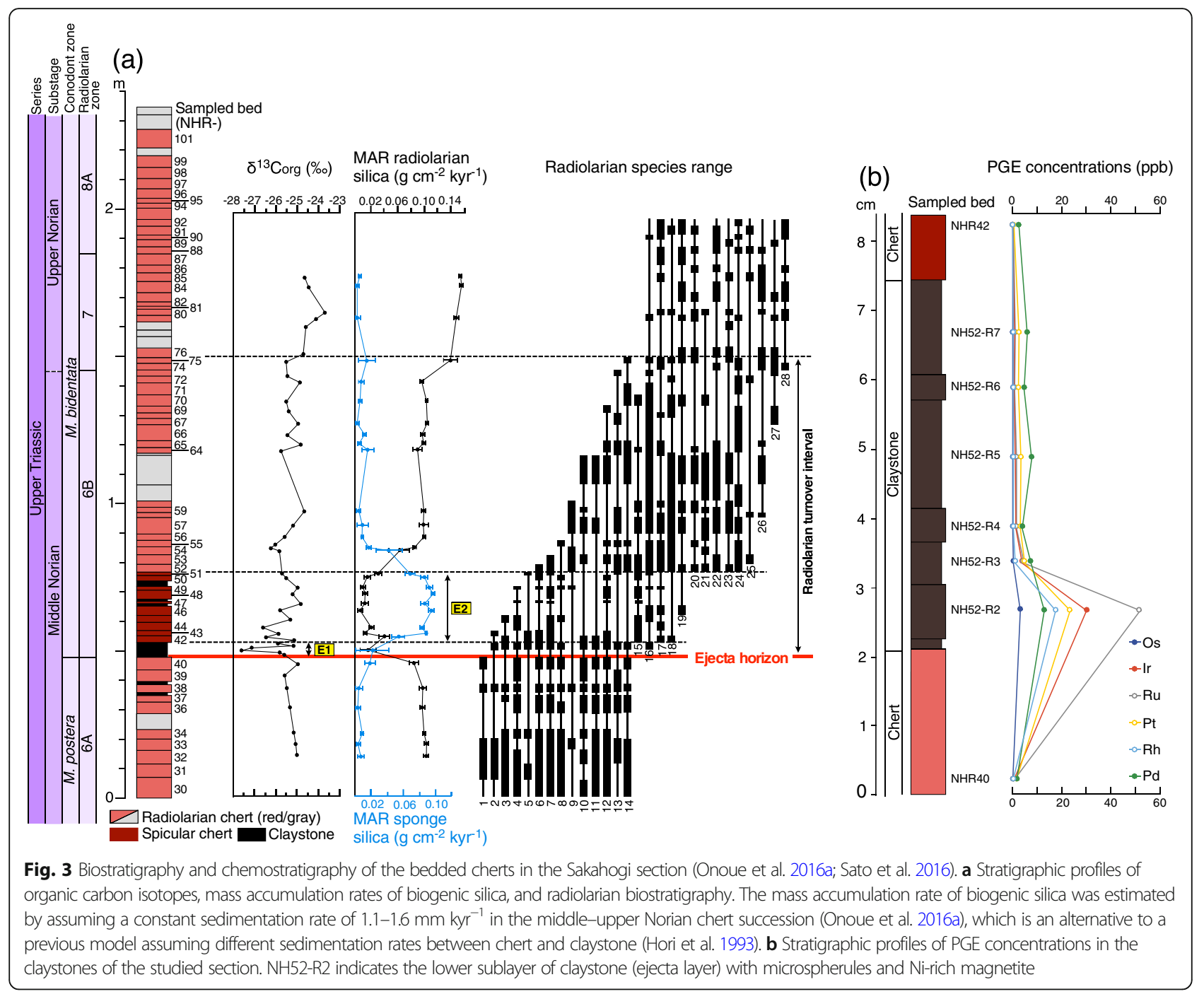

amount of biogenic silica. The second event (E2) was characterized by a large and sustained reduction in the burial flux of radiolarian silica and the proliferation of siliceous sponges. This E2 event lasted until $\sim 300 \mathrm{kyr}$ after the impact. Although the relatively long period of the E2 interval ( $300 \mathrm{kyr}$ after the impact) largely excludes the possibility that the decline was triggered by instantaneous environmental stresses (e.g., extended darkness, global cooling, or acid rain) that would have been caused by a bolide impact, the primary cause of this decline remains uncertain.

In this study, we examined variations in the compositions of major, trace, and rare earth elements (REE) in bedded cherts in the Sakahogi section to identify the environmental changes responsible for the decline in radiolarian burial flux after the middle Norian impact event. The bedded cherts were composed originally of biogenic silica, apatite, barite, clastic lithogenic materials, and hydrogenous materials such as $\mathrm{Fe}-\mathrm{Mn}$ oxides. The geochemistry of the cherts has been extensively studied in the context of the depositional environment and global environmental change (e.g., Murray et al. 1992; Hori et al. 1993; Murray 1994; Kato et al. 2002; Takiguchi et al. 2006; Hori et al. 2007). The stratigraphic variations of major and trace elements in Triassic bedded cherts from Japanese accretionary complexes are widely used as proxies to trace changes in (1) hinterland components, (2) degree of chemical weathering in hinterland regions, (3) paleoproductivity, and (4) oceanic redox conditions. In this study, we assessed temporal variations in the compositions of major, trace, and rare earth elements (REE) in the Triassic bedded cherts to investigate the biotic responses to environmental changes that occurred after the impact event in the Panthalassa Ocean.

\section{Geological setting and stratigraphy}

The Mino Belt consists of Jurassic accretionary complexes in central Japan. The accretionary complexes in 
the Mino Belt consist of two coherent units (i.e., the Samondake and Kamiaso units) and five melange units (i.e., the Sakamoto-toge, Funafuseyama, Kuze, Nabi, and Kanayama units). The coherent units consist of imbricate thrust sheets of sedimentary sequences that largely retain their primary stratigraphic coherency (e.g., Matsuda and Isozaki 1991; Isozaki 2014).

The study area in the Mino Belt is located in the Inuyama area, central Japan (Fig. 1). This area is in the southern part of the coherent Kamiaso Unit of the Mino Belt, which strikes E-W to NE-SW. The Kamiaso Unit in this area consists of thrust sheets of sedimentary sequences containing Triassic to Lower Jurassic bedded cherts and overlying Middle Jurassic clastic rocks (i.e., ocean plate stratigraphy; Isozaki 2014). The ocean plate stratigraphy is interpreted to have accumulated in a pelagic, deep-sea setting below the carbonate compensation depth and within a tapering wedge of distal, trench-fill turbidites at a subduction zone, respectively (Matsuda and Isozaki 1991). The absence of carbonate rocks and coarsegrained terrigenous material in the bedded cherts suggests that its primary depositional site was deeper than the carbonate compensation depth, and far beyond the transport distance of terrigenous clastic grains. Previous paleomagnetic studies of the Triassic bedded chert succession in the Mino Belt suggested that these sedimentary rocks accumulated in a pelagic, open-ocean setting within a low- to mid-latitudinal zone of the Panthalassa Ocean (Ando et al. 2001; Uno et al. 2015).

The Triassic to Jurassic cherts occur in 4 distinct thrusts sheets named $\mathrm{CH}-1,-2,-3$, and -4 in structurally ascending order (Yao et al. 1980). The Sakahogi section consists of a $\sim 26$ m-thick sequence of bedded cherts in the $\mathrm{CH}-2$ thrust sheet. Individual chert beds in the Sakahogi section range in thickness from 1 to $10 \mathrm{~cm}$, and are typically red to greenish gray, or occasionally white in color. The claystone layer in which PGE anomalies have been documented ranges in thickness from 4 to $5 \mathrm{~cm}$ and extends laterally for at least $90 \mathrm{~m}$ (Sato et al. 2016). The claystone comprises lower and upper sublayers (Onoue et al. 2012; Sato et al. 2013). The lower sublayer (NH52-R2) (Fig. 3b) contains microspherules within the clay mineral matrix (mainly illite), cryptocrystalline quartz, and hematite. The upper sublayer (NH52-R3 to NH52-R7) is composed of undisturbed clay minerals (illite) and cryptocrystalline quartz. The upper sublayer is further divided into five sub-categories based on variations in lithology, $\mathrm{SiO}_{2}$ content, and relative abundance of biotic components (Sato et al. 2013). The $\mathrm{SiO}_{2}$-rich sub-categories, NH52-R4 and NH52-R6, contain small amounts of radiolarians, sponge spicules, and conodonts.

Biostratigraphic and magnetostratigraphic studies $\mathrm{Su}$ giyama 1997; Onoue et al. 2012; Uno et al. 2015; Yamashita et al. 2018) have revealed that the claystone layer occurs in upper middle Norian bedded chert. Given that the average sedimentation rate of the middle Norian chert, estimated from the measured thickness of the chert and the duration of deposition (Onoue et al. 2016a), is $1.1 \mathrm{~mm} \mathrm{kyr}^{-1}$, deposition of the claystone layer occurred $\sim 1$ Myr before the middle-upper Norian boundary ( $214 \mathrm{Ma}$; Ogg 2012). Although the ages of substage boundaries in the Norian remain unclear due to a lack of reliable radio-isotopic dates and uncertainties in the magnetostratigraphic correlation between the Newark astrochronological polarity time scale (APTS) and marine-zoned strata (Ogg 2012), Onoue et al. (2016a) estimated the average sedimentation rate of the middle Norian chert based on the measured thickness $(3.8 \mathrm{~m})$ of the chert and the duration between the lower/ middle (217.42 Ma) and middle/late Norian (213.97 Ma) boundaries (Ogg 2012).

\section{Methods/Experimental}

\subsection{Major and trace elements analyses}

To understand the environmental changes that triggered the decline in radiolarian burial flux after the middle Norian impact event, fifty-seven chert samples were collected across the ejecta layer for whole-rock geochemical analysis (Fig. 3). We also collected 6 claystone samples from the lower and upper sublayers. Veins and strongly recrystallized/weathered parts of the samples were avoided to minimize the effects of diagenetic and metamorphic overprinting on the sediment geochemistry. The chert and claystone samples were crushed, and the resulting fragments were carefully handpicked. These fragments were then powdered in an agate mortar and ball mill.

Major element ( $\mathrm{Ti}, \mathrm{Al}, \mathrm{Fe}, \mathrm{Mn}, \mathrm{K}$, and $\mathrm{P}$ ) abundances were measured using a Rigaku ZSX Primus II X-ray fluorescence (XRF) spectrometer at the University of Tokyo, Japan, following the methods described by Kato et al. (1998) and Yasukawa et al. (2014). After drying the powdered samples at $110{ }^{\circ} \mathrm{C}$ for $\sim 12 \mathrm{~h}$, loss-on-ignition (LOI) values were calculated from the weight loss after ignition at $950{ }^{\circ} \mathrm{C}$ for $>6 \mathrm{~h}$. Fused glass beads for XRF analysis were made from a mixture of $0.400 \mathrm{~g}$ of ignited sample powder and $4.00 \mathrm{~g}$ of lithium tetraborate $\left(\mathrm{Li}_{2} \mathrm{~B}_{4} \mathrm{O}_{7}\right)$ flux at $\sim 1190{ }^{\circ} \mathrm{C}$ for $7 \mathrm{~min}$ in a Pt crucible. The standard data were generally within 3\% (relative \% difference) of accepted values for the reference basalt JB2 (Imai et al. 1995), issued by the Geological Survey of Japan (GSJ).

Major ( $\mathrm{Mg}, \mathrm{Ca}$, and $\mathrm{Na}$ ), trace, and REE abundances were determined using an inductively coupled plasma quadrupole mass spectrometer (ICP-QMS; Agilent 7500c) at the University of Tokyo, following procedures described by Kato et al. $(2005,2011)$ and Yasukawa et al. (2014). After drying powdered samples at $110{ }^{\circ} \mathrm{C}$ for $\sim 12$ 
h, $0.100 \mathrm{~g}$ chert and $0.050 \mathrm{~g}$ claystone samples were dissolved by $\mathrm{HNO}_{3}-\mathrm{HF}-\mathrm{HClO}_{4}$ digestion in tightly sealed Teflon PFA vessels, and then heated for several hours on a hot plate at $130{ }^{\circ} \mathrm{C}$. The dissolved samples were progressively evaporated at $110{ }^{\circ} \mathrm{C}$ for $12 \mathrm{~h}, 160{ }^{\circ} \mathrm{C}$ for $3 \mathrm{~h}$, and $190{ }^{\circ} \mathrm{C}$ until dryness. The residues were then dissolved in $4 \mathrm{~mL}$ of $\mathrm{HNO}_{3}$ and $1 \mathrm{~mL}$ of $\mathrm{HCl}$, and the solution was diluted to 1:1000 for the cherts and 1:2000 for the claystones (on a weight basis). Standard analyses were generally within 5\% of the accepted values for JB-2 (Imai et al. 1995; Makishima and Nakamura 2006; Lu et al. 2007).

\section{Results}

\subsection{Major and trace elements}

Major and trace element data are listed in Tables 1, 2 , and 3. Previous sedimentological and geochemical studies revealed that the chert beds in the Sakahogi section consist of $\mathrm{SiO}_{2}$-diluted siliceous shale beds, reflecting fluctuations in radiolarian test abundances (Hori et al. 1993; Takiguchi et al. 2006; Sato et al. 2013). In fact, the chert bed samples contain $>90$ wt.\% $\mathrm{SiO}_{2}$, which means the other major and trace elements are diluted by a large amount of biogenic silica. In particular, abundances of the major lithogenic elements, such as $\mathrm{Al}_{2} \mathrm{O}_{3}, \mathrm{~K}_{2} \mathrm{O}$, and $\mathrm{TiO}_{2}$, show a negative correlation with $\mathrm{SiO}_{2}$ contents. This is attributed to dilution with nearly pure biogenic silica (e.g., radiolarians), as exemplified by the $\mathrm{SiO}_{2}-\mathrm{Al}_{2} \mathrm{O}_{3}$, $\mathrm{SiO}_{2}-\mathrm{K}_{2} \mathrm{O}$, and $\mathrm{SiO}_{2}-\mathrm{TiO}_{2}$ plots (Fig. 4). We assumed the $\mathrm{SiO}_{2} / \mathrm{Al}_{2} \mathrm{O}_{3}$ ratio of terrigenous material in the Sakahogi section was 4.1, which is that of a sample with the highest $\mathrm{Al}_{2} \mathrm{O}_{3}$ content in the section (Fig. 4) and comparable to the ratio ( 4.3) of upper continental crust (UCC; Rudnick and Gao 2014).

The data for the chert beds demonstrate that $\mathrm{Al}$ shows an excellent positive correlation with high-field-strength (HFS) elements such as Ti, Nb, Ta, and Th (Fig. 5). Considering the fact that $\mathrm{Al}, \mathrm{Ti}, \mathrm{Nb}, \mathrm{Ta}$, and $\mathrm{Th}$ are not significantly mobilized during post-depositional processes, including diagenesis and weathering, these correlations indicate that the majority of these elements are of detrital origin. The $\mathrm{Ti} / \mathrm{Al}, \mathrm{Nb} / \mathrm{Al}, \mathrm{Ta} / \mathrm{Al}$, and $\mathrm{Th} / \mathrm{Al}$ ratios are identical to those of average UCC (Rudnick and Gao 2014) (Fig. 5). The present study also revealed that $\mathrm{K}$ and $\mathrm{Rb}$ correlate well with $\mathrm{Al}, \mathrm{Ti}, \mathrm{Nb}, \mathrm{Zr}, \mathrm{Hf}$, and $\mathrm{Th}$, but their $\mathrm{Al}$-normalized ratios are different from those of UCC. In addition, $\mathrm{Zr} / \mathrm{Hf}$ and $\mathrm{Nb} / \mathrm{Ta}$ values obtained from chert and claystone samples show a strong linear correlation, and are comparable to those of average UCC (Fig. 6).

To avoid the significant dilution effect by biogenic $\mathrm{SiO}_{2}$, concentrations of the elements were normalized to $\mathrm{Al}$ concentrations and compared with those of the UCC
(Rudnick and Gao 2014) to obtain enrichment factors. The enrichment factor is defined as follows:

$$
\mathrm{X}_{\mathrm{EF}}=\left(\mathrm{X}_{\text {sample }} / \mathrm{Al}_{\text {sample }}\right) /\left(\mathrm{X}_{\mathrm{UCC}} / \mathrm{Al}_{\mathrm{UCC}}\right)
$$

where $\mathrm{X}$ and $\mathrm{Al}$ are the concentrations of element $\mathrm{X}$ and $\mathrm{Al}$, respectively. Furthermore, to minimize the possibility of diagenetic redistribution of elements from layers with lower $\mathrm{SiO}_{2}$ content to adjacent layers with higher $\mathrm{SiO}_{2}$ content (Tada 1991), we excluded the elemental data for non-detrital elements from $\mathrm{SiO}_{2}$-poor parts of the claystone samples (NH52-R2, -R3, -R5, and -R7) when reconstructing the stratigraphic variations in enrichment factors.

Figures 7 and 8 show stratigraphic variations of enrichment factors for terrigenous elements, including HFS elements ( $\mathrm{Ti}, \mathrm{Ta}, \mathrm{Nb}, \mathrm{Hf}$, and $\mathrm{Zr}$ ) and alkali elements $(\mathrm{K}$ and $\mathrm{Rb}) . \mathrm{Ti}_{\mathrm{EF}}, \mathrm{Nb}_{\mathrm{EF}}$, and $\mathrm{Ta}_{\mathrm{EF}}$ values are relatively constant throughout the studied section and close to a UCC value of 1 . However, the lower sublayer claystone (NH52-R2) exhibits higher $\operatorname{Ti}_{\mathrm{EF}}(\sim 1.5)$ than those of other upper claystone and chert beds. Changes in $\mathrm{Zr}_{\mathrm{EF}}$ and $\mathrm{Hf}_{\mathrm{EF}}$ are also parallel to the UCC line in the studied interval. $\mathrm{K}_{\mathrm{EF}}$ and $\mathrm{R} \mathrm{b}_{\mathrm{EF}}$ vary between $1.12-1.75$ and 1.62.4 , respectively (Fig. 8 ). The $K_{E F}$ and $R b_{E F}$ values decreased during the E2 event.

Vanadium, U, and Mo form highly soluble ions under oxygenated conditions, but under anoxic conditions, they are insoluble and in a lower valency state (Calvert and Pedersen 1993; Calvert and Pedersen 2007). Enrichment factors of these redox-sensitive elements are generally parallel to the UCC line in the studied interval (Fig. 7). Similarly, there are no significant changes in the enrichment factors of $\mathrm{Ni}$ and $\mathrm{Zn}$ (Table 2), which form highly insoluble sulfides under suboxic and/or anoxic bottom water conditions (Calvert and Pedersen 1993).

$\mathrm{Si}, \mathrm{Ca}, \mathrm{Sr}, \mathrm{P}$, and $\mathrm{Ba}$ are widely used as proxies for burial flux of biogenic material (Hollis 2003; Hollis et al. 2003; Takiguchi et al. 2006), based on their distribution in modern marine sediments (e.g., Schroeder et al. 1997). Stratigraphic variations of enrichment factors for these elements are shown in Fig. 7. $\mathrm{Si}_{\mathrm{EF}}$ abruptly decreased during the initial E1 interval where the burial flux of silica-secreting radiolarians was markedly reduced (Onoue et al. 2016a). The trend in $\mathrm{Ca}_{\mathrm{EF}}$ is similar to those of $\mathrm{P}_{\mathrm{EF}}$ and $\mathrm{Sr}_{\mathrm{EF}}$, and there are strong positive correlations between $\mathrm{Ca}_{\mathrm{EF}}$ and $\mathrm{P}_{\mathrm{EF}}(r=0.93)$ (Fig. 9). As with the $\mathrm{Si}_{\mathrm{EF}}$ trend, there is an abrupt decrease in $\mathrm{Ca}_{\mathrm{EF}}$, $\mathrm{P}_{\mathrm{EF}}$, and $\mathrm{Sr}_{\mathrm{EF}}$ during the initial E1 event, and these values began to rise after the $\mathrm{E} 2$ event. $\mathrm{Ba}_{\mathrm{EF}}$ values also decreased sharply during the E1 interval, and were relatively constant after the E2 interval. 


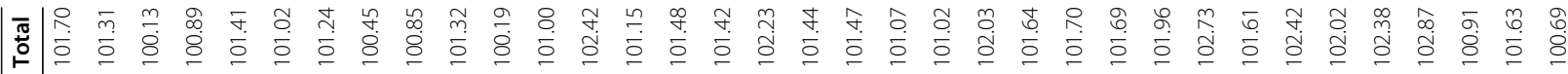

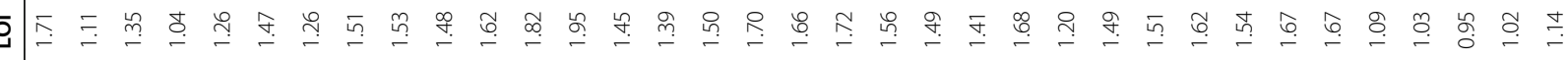

沙

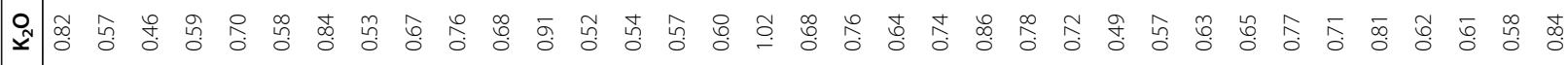

吕

ᄋ

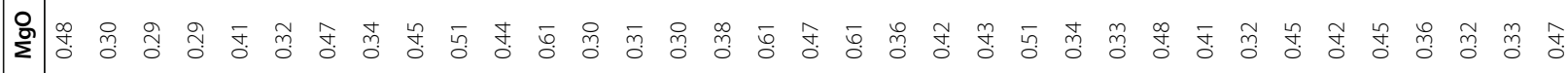

胥

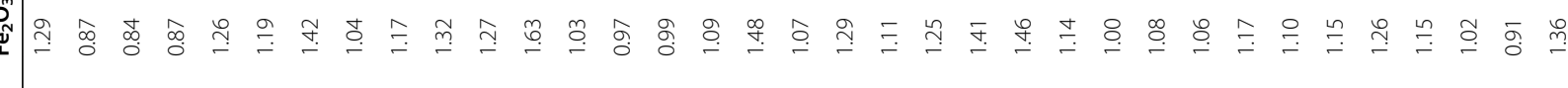

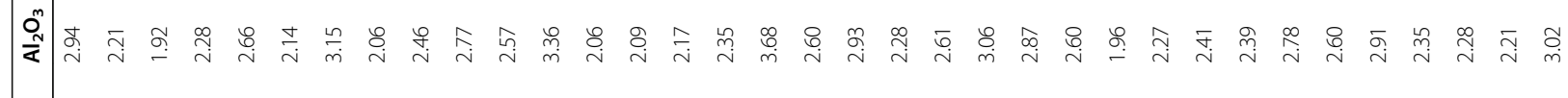

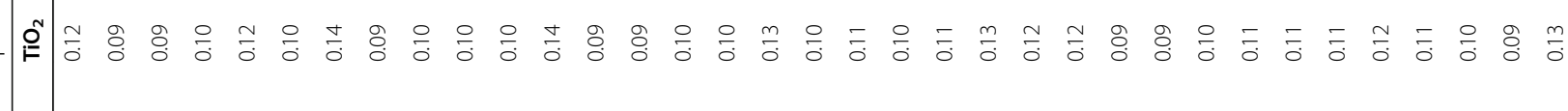

ஸी

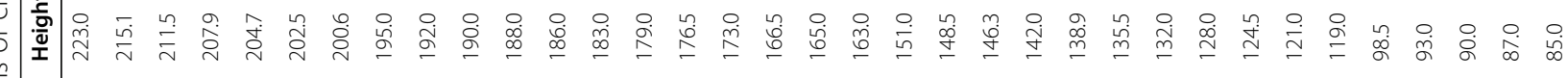

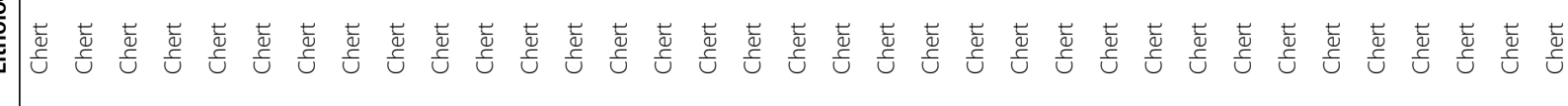




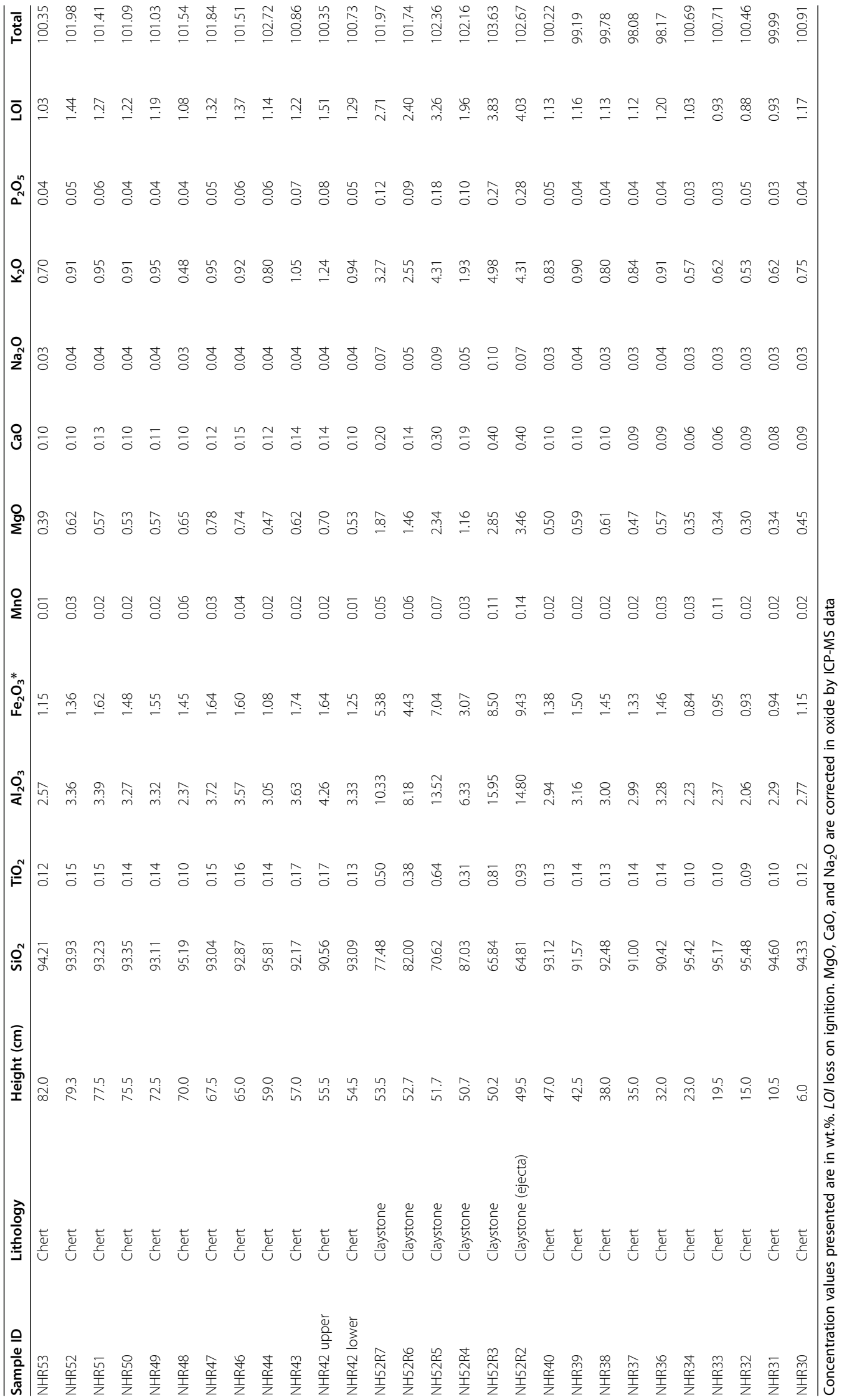




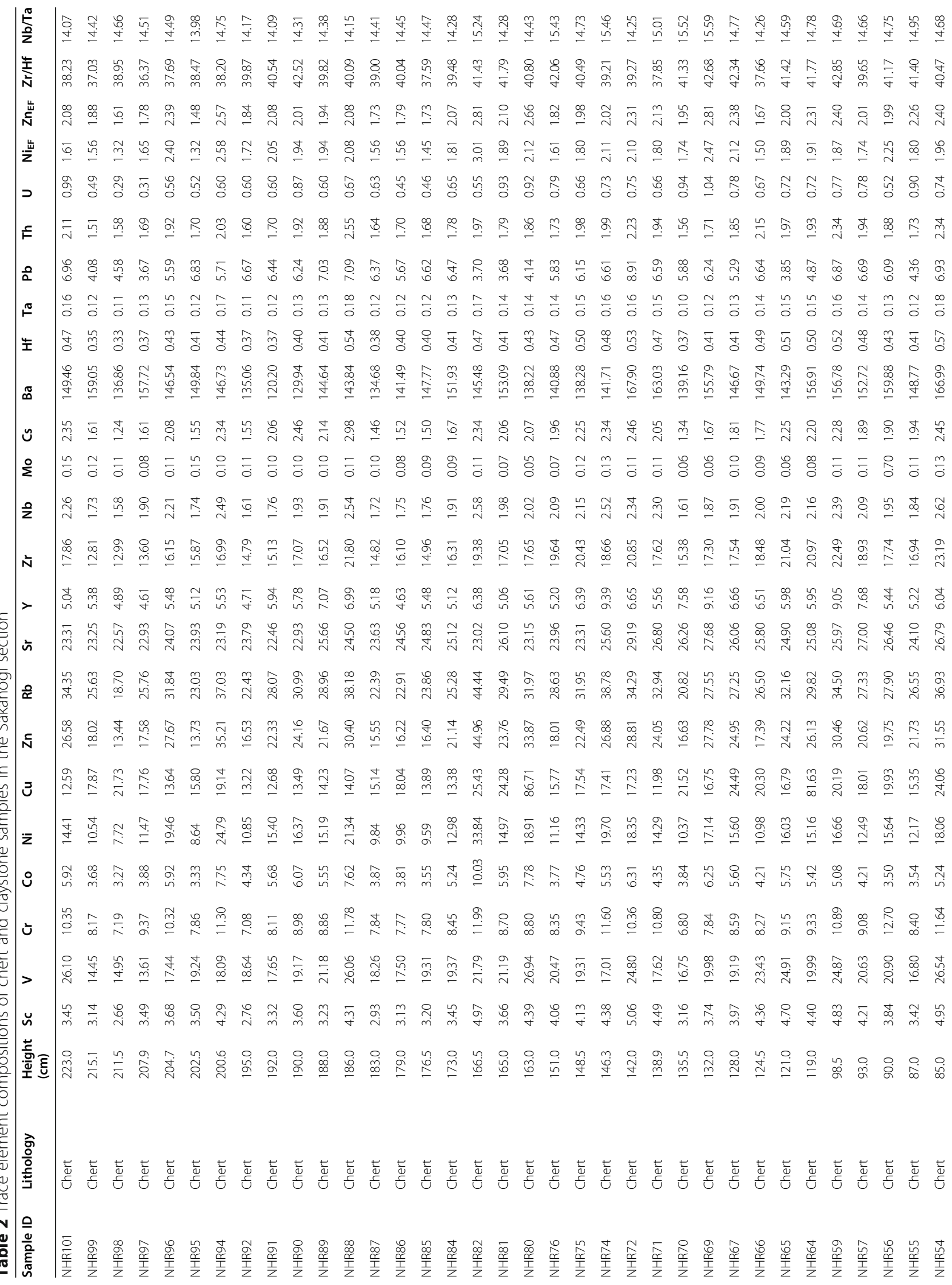




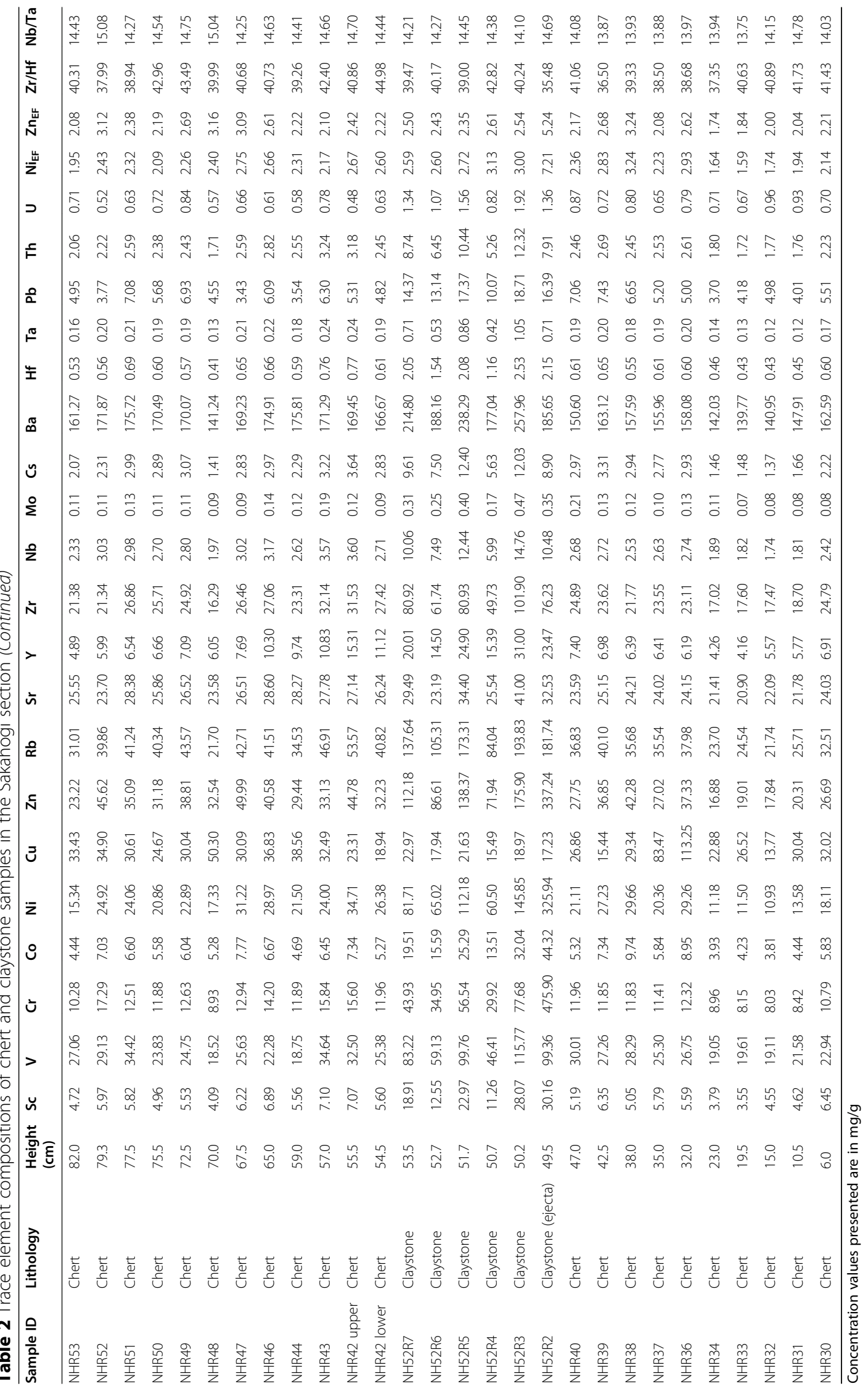




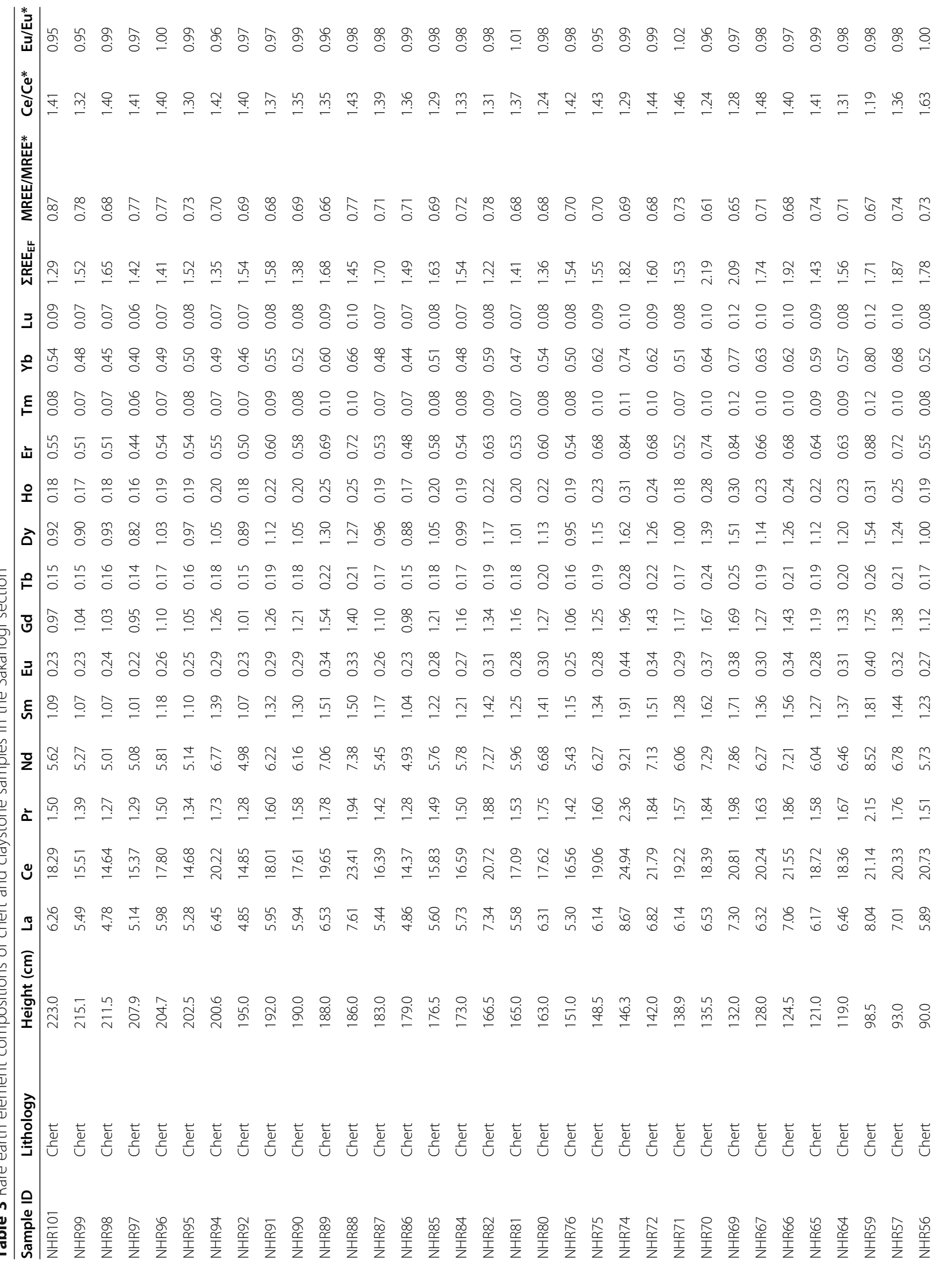




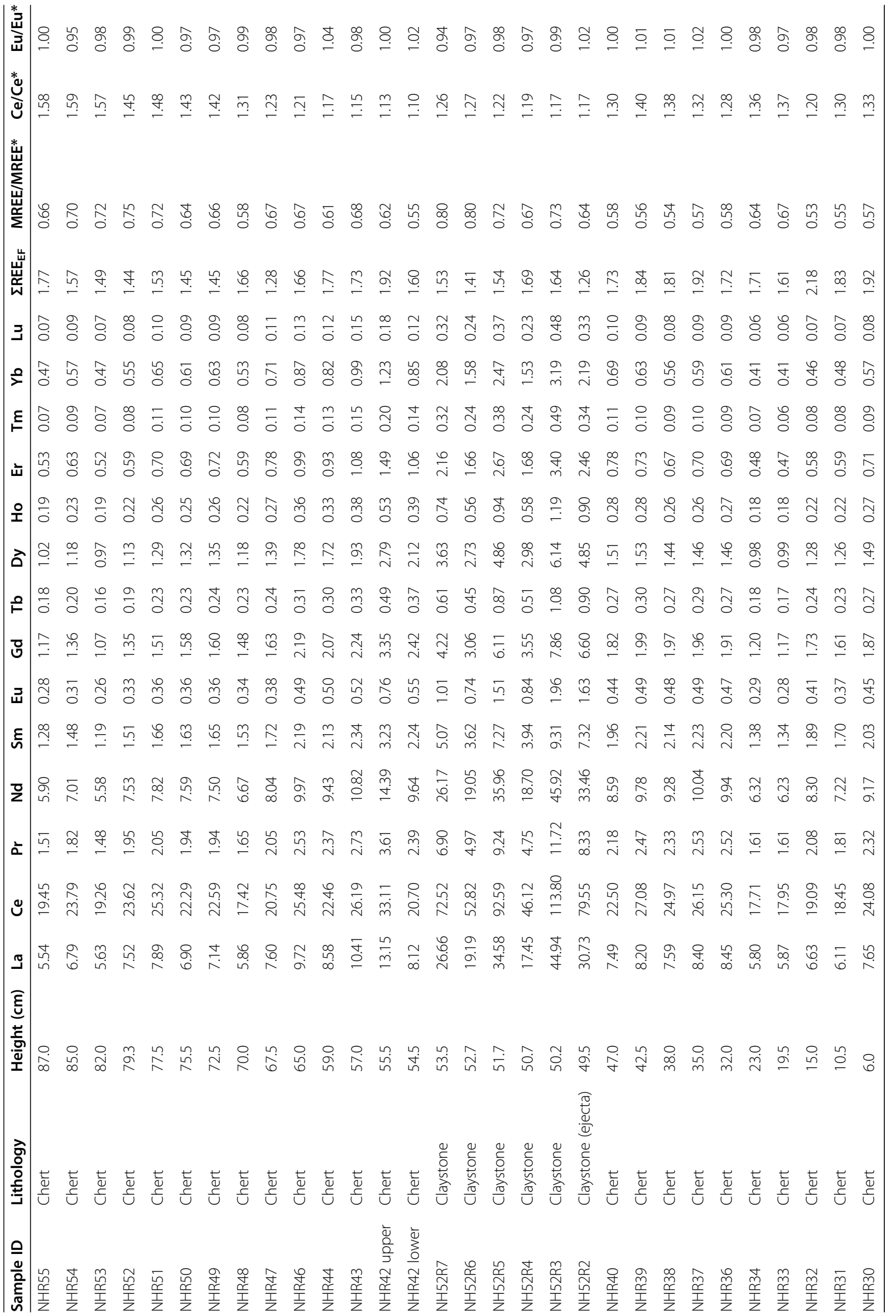



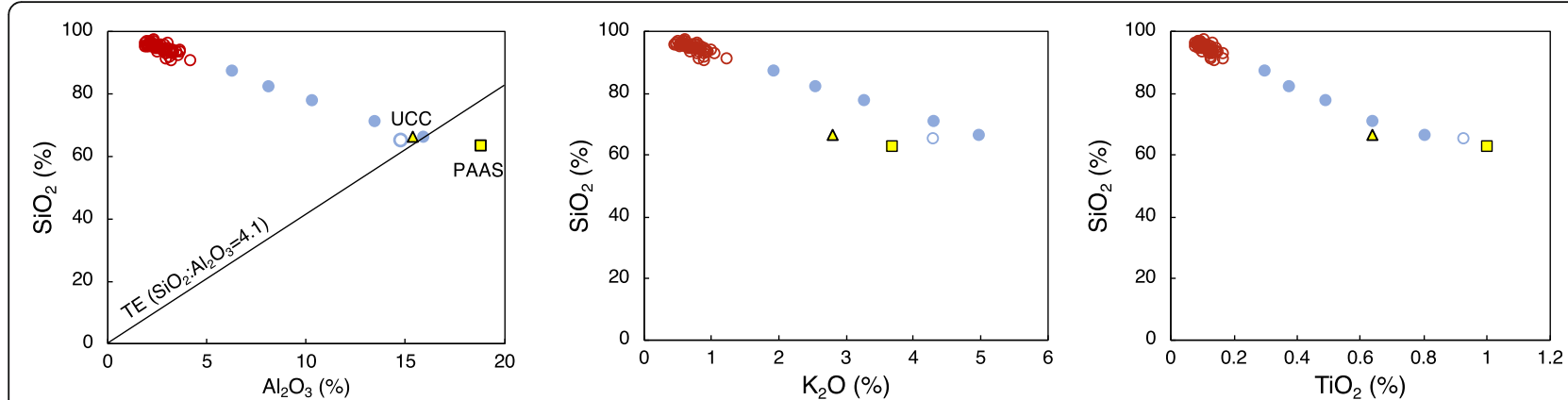

Fig. 4 Plots of $\mathrm{SiO}_{2}$ vs. $\mathrm{Al}_{2} \mathrm{O}_{3}, \mathrm{~K}_{2} \mathrm{O}$, and $\mathrm{TiO}_{2}$ for the chert and claystone samples. Chert (red open circles) and lower (blue open circles) and upper (blue filled circles) claystone samples exhibit negative correlations, indicating dilution with biogenic silica (e.g., radiolarians). TE terrigenous material in the Sakahogi section, UCC upper continental crust, PAAS post-Archean average Australian shale. Data sources: UCC (Rudnick and Gao 2014); PAAS (Taylor and McLennan 1985)
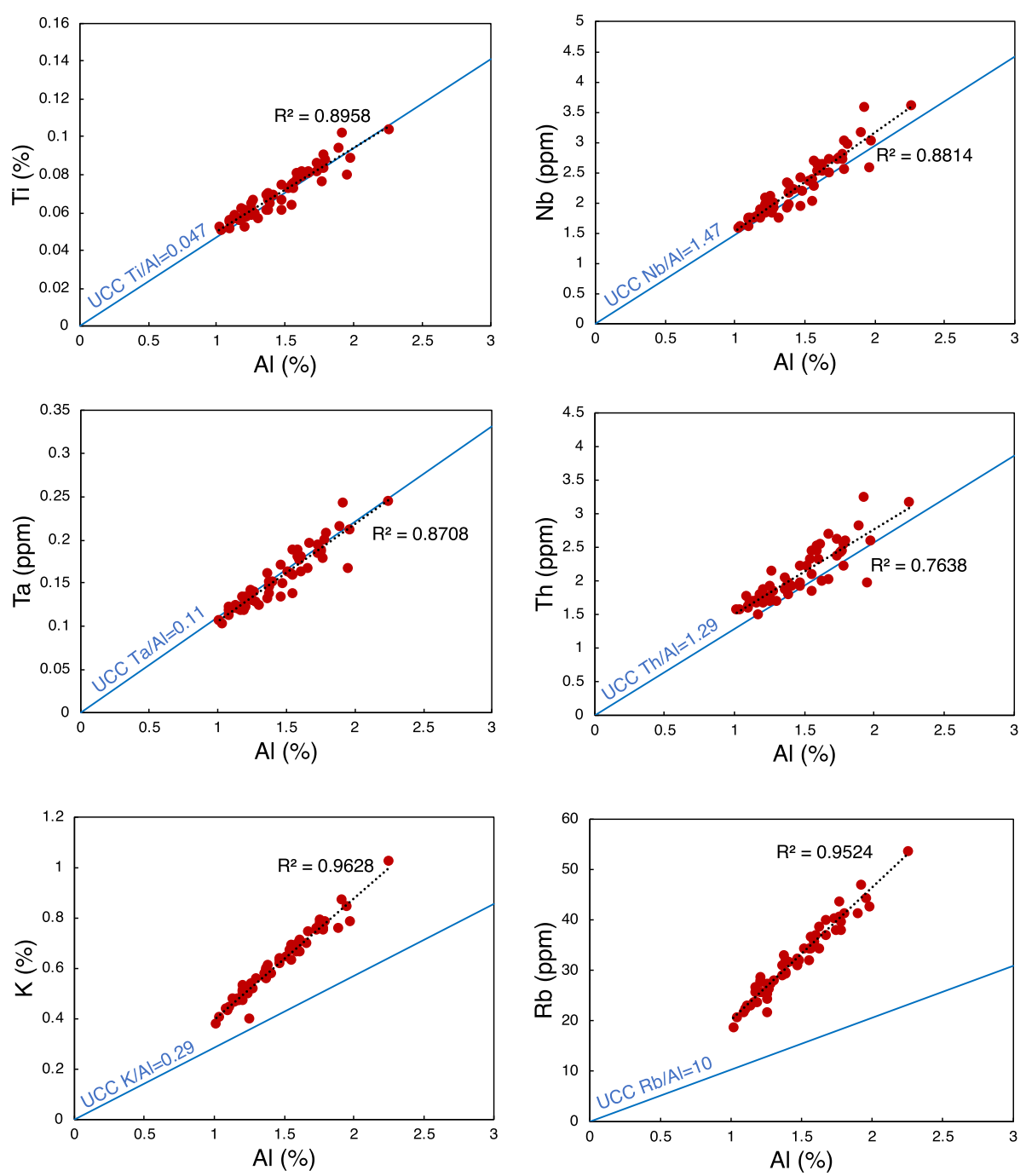

Fig. 5 Plots of Al vs. Ti, Nb, Ta, Th, K, and Rb for the chert samples. Ti/Al, Nb/Al, Ta/Al, and Th/Al ratios are identical to those of average UCC (Rudnick and Gao 2014), whereas K/Al and Rb/Al ratios are significantly higher than those of UCC 

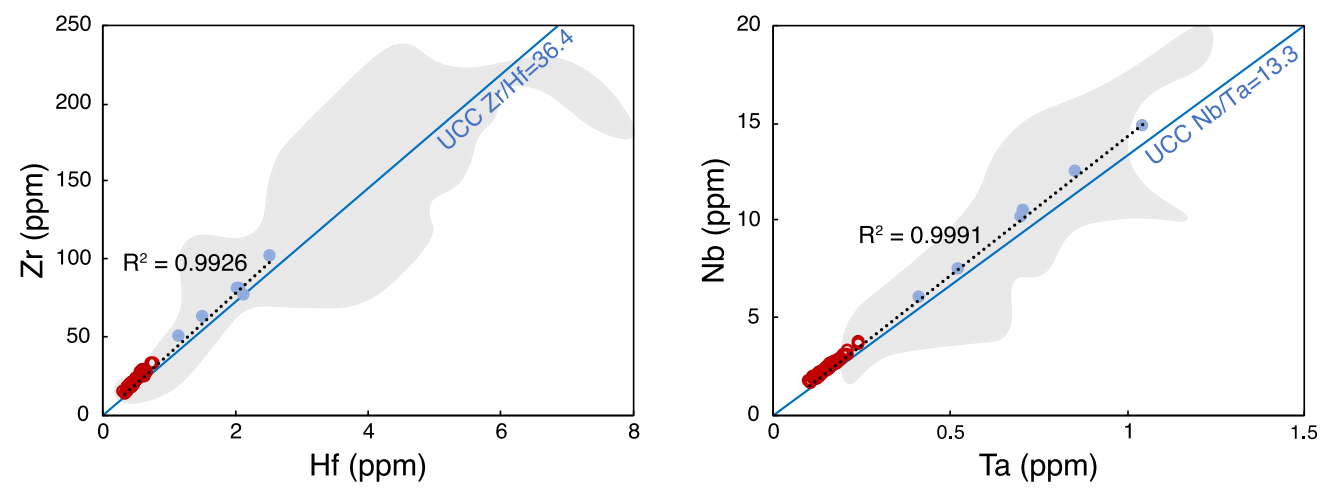

Fig. 6 Plots of Zr vs. Hf and Nb vs. Ta for chert (open red circles) and claystone (filled blue circles) samples. Compilation of modern deep-sea sediments (gray field; Plank and Langmuir 1998) are also shown for comparison

\subsection{Rare earth elements}

Table 3 lists the REE concentrations of the chert and claystone samples in the studied section. Enrichment factors of the total REE concentrations $\left(\sum \mathrm{REE}_{\mathrm{EF}}\right)$ have positive correlations with $\mathrm{Ca}_{\mathrm{EF}}$ and $\mathrm{P}_{\mathrm{EF}}$ and are also positively correlated with some trace elements, such as $\mathrm{Zr}_{\mathrm{EF}}, \mathrm{Hf}_{\mathrm{EF}}$, and $\mathrm{Th}_{\mathrm{EF}}$ (Fig. 9). Figure 10 shows the $\mathrm{REE}$ patterns of chert and claystone beds across the impact ejecta layer normalized to UCC (Rudnick and Gao 2014). Enrichment of the middle REEs (MREEs; Sm, Gd, $\mathrm{Tb}$, and Dy) exhibits stratigraphic changes. The chert beds throughout the whole section are relatively enriched in MREEs, whereas REE patterns for the claystones (NH52-R2 to R7) are relatively flat with nearly UCC values (Fig. 10). To calculate the relative MREE enrichments, UCC-normalized MREE/MREE* ratios were used (Chen et al. 2015):

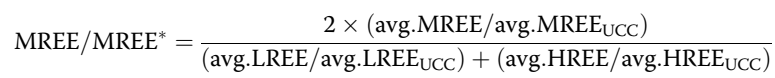

where LREE and HREE represent light REEs (La, Ce, Pr, and $\mathrm{Nd}$ ) and heavy REEs (Er, Tm, Yb, and $\mathrm{Lu}$ ) respectively.

The MREE/MREE* ratios across the ejecta layer show a decrease in MREE enrichment after the impact event. The average MREE/MREE* ratio in cherts below the ejecta layer is 1.35 , whereas in the E1 interval it is 1.12 . The MREE/MREE* ratios rapidly increase in the chert beds of the E2 interval, indicating a pronounced decline in MREE enrichment during the E1 interval.

$\mathrm{Ce}$ and $\mathrm{Eu}$ are the only two REEs that have multiple valence states, which results in fractionation that can be quantified by $\mathrm{Ce}$ and $\mathrm{Eu}$ anomalies (German and Elderfield 1989; German and Elderfield 1990; Holser 1997). Cerium and $\mathrm{Eu}$ anomalies are calculated as:

$$
\begin{aligned}
& \mathrm{Ce} / \mathrm{Ce}^{*}=2 \mathrm{Ce}_{N} /\left(\mathrm{La}_{N}+\operatorname{Pr}_{N}\right) \\
& \mathrm{Eu} / \mathrm{Eu}^{*}=2 \mathrm{Eu}_{N} /\left(\mathrm{Sm}_{N}+\mathrm{Gd}_{N}\right)
\end{aligned}
$$

The subscript " $N$ " denotes UCC-normalized values. $\mathrm{Ce} / \mathrm{Ce}^{*}$ values exhibit positive anomalies and vary from 1.10-1.63 throughout the studied section (Fig. 11). Ce/ $\mathrm{Ce}^{*}$ values fluctuate during the radiolarian turnover interval (Fig. 11), but are essentially uniform after this interval. There are no $\mathrm{Eu}$ anomalies relative to UCC through the studied section (Fig. 10). The average Eu/ $\mathrm{Eu}^{*}$ value of the studied section is $0.98 \pm 0.02$.

\section{Discussion}

On the basis of high-resolution profiles of biogeochemical signatures $(\mathrm{Si}, \mathrm{Ba}, \mathrm{Ca}$, and $\mathrm{P})$, redox-sensitive elements, REE, and Chemical Index of Alteration (CIA; Nesbitt and Young 1982) values obtained from the Triassic bedded cherts, we assessed the environmental changes that triggered a decline in radiolarian burial flux after the Norian impact event. Here, we consider three of the main environmental changes (paleoproductivity, oceanic redox conditions, and provenance) before discussing the triggers for the decline in radiolarian burial flux based on these controls.

\subsection{Paleoproductivity}

Changes in marine primary productivity may have played an important role at the base of the marine food chain after the middle Norian impact event. A postimpact reduction in primary productivity has been suggested based on the negative $\delta^{13} \mathrm{C}_{\text {org }}$ excursion observed during the E1 event (Onoue et al. 2016a). To evaluate productivity estimates based on $\delta^{13} C_{\text {org }}$ data, we used $\mathrm{Ba}_{\mathrm{EF}}$ as another proxy for primary productivity. It is generally considered that barite precipitation occurs in decaying particulate organic matter while it sinks to the 


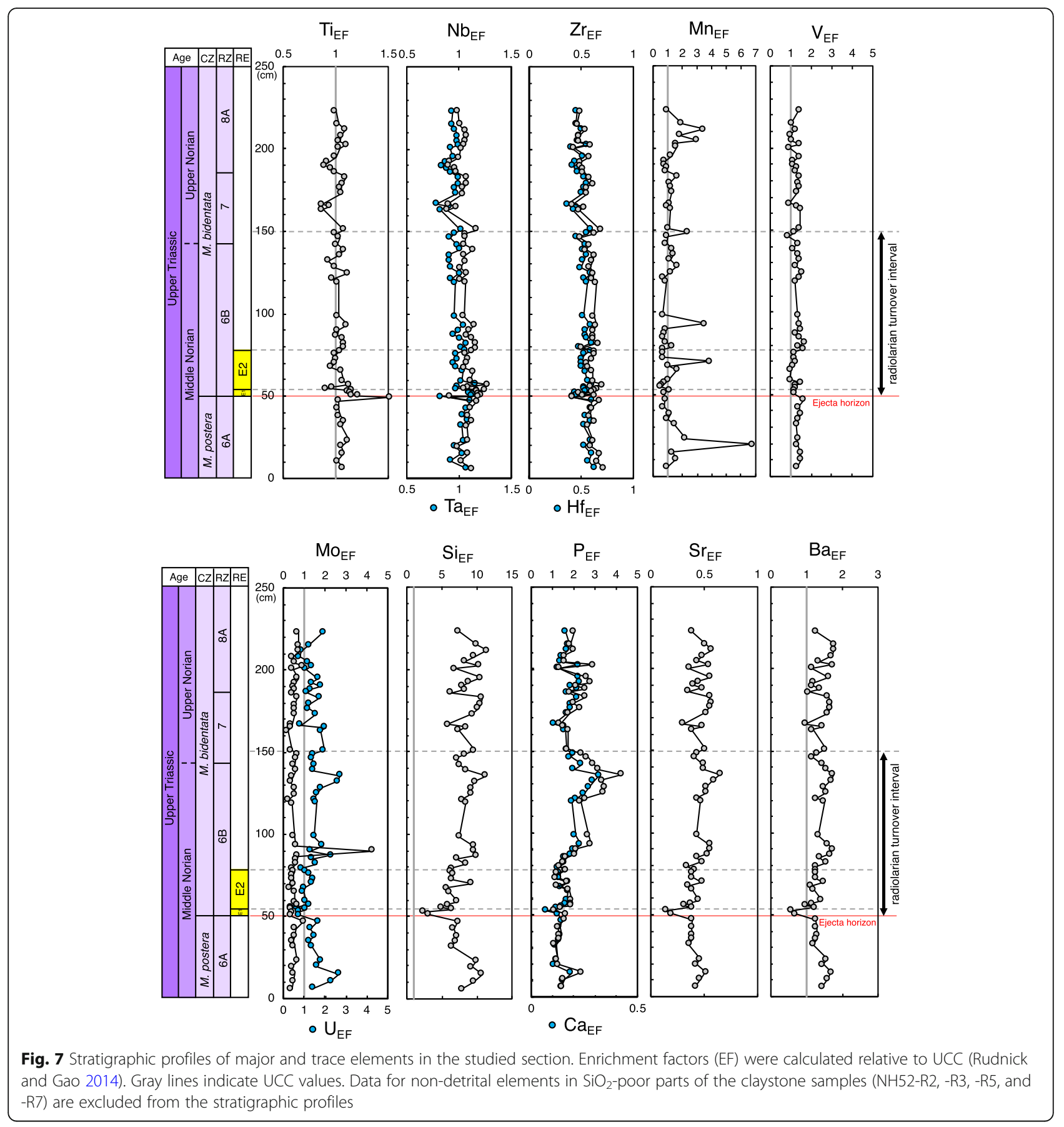

seafloor (Dehairs et al. 1980; Bishop 1988; Dymond and Collier 1996). Enhanced $\mathrm{Ba}_{\mathrm{EF}}$ values below highproductivity areas support this assumption (Nürnberg et al. 1997). Given that pore water in a sediment column is generally saturated with respect to barite, the barite associated with productivity can be preserved after burial. Therefore, the $\mathrm{Ba}_{\mathrm{EF}}$ record of the bedded cherts can be used as a proxy for productivity variations in the surface ocean (e.g., Zachos et al. 1989; Dymond and Collier
1996; McManus et al. 1998; Algeo et al. 2011). Our data show that $\mathrm{Ba}_{\mathrm{EF}}$ in the studied section decreases in the $\mathrm{E} 1$ interval and recovers in the E2 interval. The stratigraphic profile of $\mathrm{Ba}_{\mathrm{EF}}$ mimics that of $\delta^{13} \mathrm{C}_{\mathrm{org}}$, which supports the previous interpretation of $\delta^{13} \mathrm{C}_{\text {org }}$ records that marine primary productivity decreased in the E1 interval and recovered in the E2 interval (Onoue et al. 2016a).

Phosphorous is also a geochemical proxy for paleoproductivity in pelagic deep-sea sediments (e.g., Murray and 


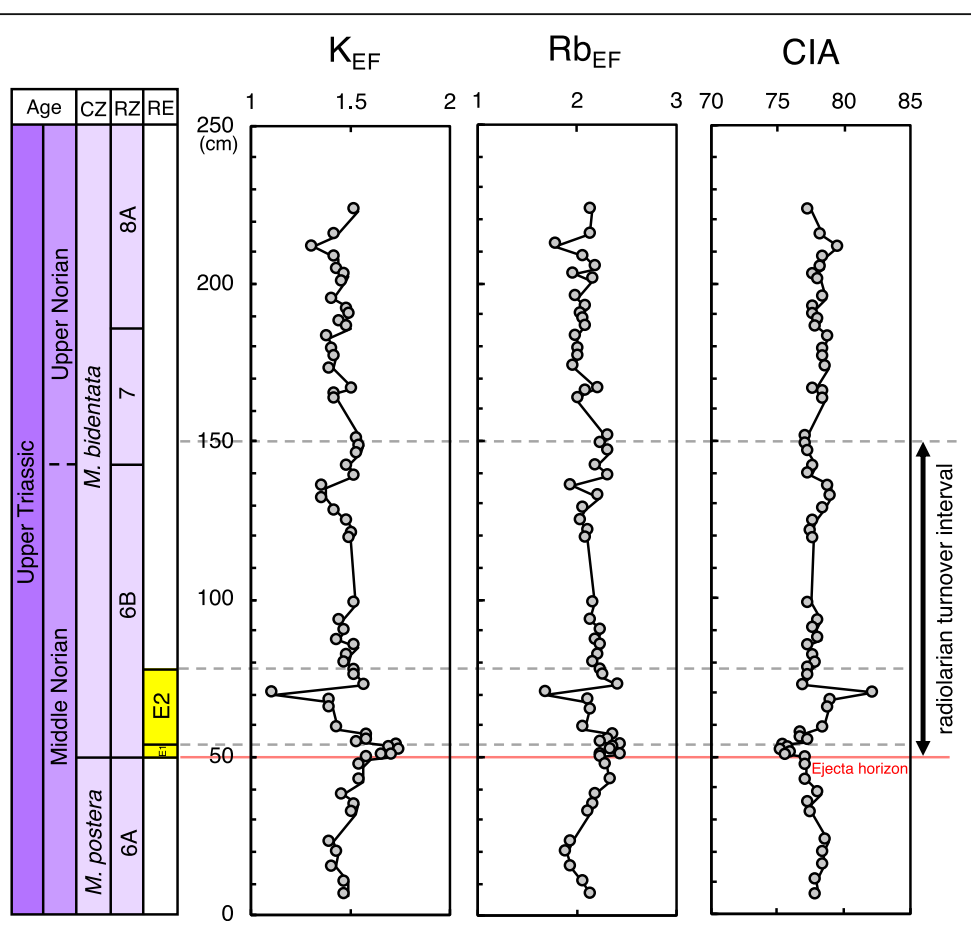

Fig. 8 Stratigraphic profiles of $\mathrm{K}_{\mathrm{EF}}, \mathrm{Rb}_{\mathrm{EF}}$, and $\mathrm{CIA}$ in the studied section. Enrichment factors (EF) were calculated relative to UCC (Rudnick and GaO 2014). $K_{E F}$ and $R b_{E F}$ decrease with increasing $C I A$ values during the $E 2$ event

Leinen 1993; Algeo et al. 2011). Phosphorous is transferred to the sediment mainly as organically bound P, most of which is subsequently liberated through remineralization of organic matter; long-term retention of $\mathrm{P}$ in sediment requires adsorption onto ferric oxyhydroxide and subsequent mineralization as authigenic phosphates (Algeo and Ingall 2007). For our samples, a strong positive correlation between $\mathrm{P}_{\mathrm{EF}}$ and $\mathrm{Ca}_{\mathrm{EF}}(r=$ 0.93) implies that the apatite species is the main host phase for $\mathrm{P} . \mathrm{P}_{2} \mathrm{O}_{5} / \mathrm{CaO}$ ratios of Triassic conodonts, or biogenic apatite, obtained from a bedded chert succession in Inuyama area range from 0.71 to 0.77 with an average of 0.74 (Takiguchi et al. 2006). The $\mathrm{P}_{2} \mathrm{O}_{5} / \mathrm{CaO}$ obtained from our samples is almost identical $\left(\mathrm{P}_{2} \mathrm{O}_{5} /\right.$ $\mathrm{CaO}=0.72)$ to those of conodonts. These data suggest that biogenic apatite such as conodonts is preserved in our samples as the main carrier of $\mathrm{Ca}$ and $\mathrm{P}$. Thus, $\mathrm{P}_{\mathrm{EF}}$ cannot be used as a proxy for primary productivity in the studied section, but instead $\mathrm{P}_{\mathrm{EF}}$ and $\mathrm{Ca}_{\mathrm{EF}}$ reflect biogenic apatite (i.e., conodonts) accumulation relative to terrigenous accumulation in the bedded cherts.

The stratigraphic variations in $\mathrm{Ca}_{\mathrm{EF}}$ and $\mathrm{P}_{\mathrm{EF}}$ indicate that the accumulation of biogenic apatite decreased during the E1 interval, whereas its accumulation recovered after the E2 interval (Fig. 7). Strontium is geochemically similar to $\mathrm{Ca}$ and may replace $\mathrm{Ca}$ in apatite, which is supported by the positive correlation between $\mathrm{Sr}_{\mathrm{EF}}$ and $\mathrm{Ca}_{\mathrm{EF}}(r=0.76)$. Significant negative excursions in $\mathrm{Sr}_{\mathrm{EF}}$ in the E1 interval may also reflect a decrease in biogenic apatite accumulation.

Additional information regarding changes in biogenic apatite accumulation may be derived from REE data. The UCC-normalized REE patterns of the bulk chert samples show slight MREE enrichment (Fig. 10), which is probably due to the presence of fossil biogenic apatite that recrystallized during diagenetic processes (Reynard et al. 1999; Chen et al. 2015). The claystones in the E1 interval have similar LREE and HREE abundances, but slightly different MREE abundances, resulting in a flatter pattern in that interval. Relative depletion of MREEs in the claystone samples is probably due to the paucity of conodont fossils, which is consistent with the interpretation that the decrease in $\mathrm{Ca}_{\mathrm{EF}}$ and $\mathrm{P}_{\mathrm{EF}}$ was associated with decreased accumulation of biogenic apatite during the E1 interval.

The oxygen isotopic composition of conodont apatite derived from Late Triassic deep-marine sediment sections in the western Tethys has revealed that conodont $\delta^{18} \mathrm{O}$ values reflect surface water temperatures and that these conodonts lived in near-surface waters (Rigo and Joachimski 2010; Rigo et al. 2012). Thus, significant negative excursions in $\mathrm{Ca}_{\mathrm{EF}}$ and $\mathrm{P}_{\mathrm{EF}}$ in the $\mathrm{E} 1$ interval may reflect a decrease in biogenic apatite accumulation by conodonts in near-surface waters in a pelagic realm of the Panthalassa Ocean. $\delta^{13} \mathrm{C}_{\mathrm{org}}$ and $\mathrm{Ba}_{\mathrm{EF}}$ data also imply that primary productivity in the pelagic 


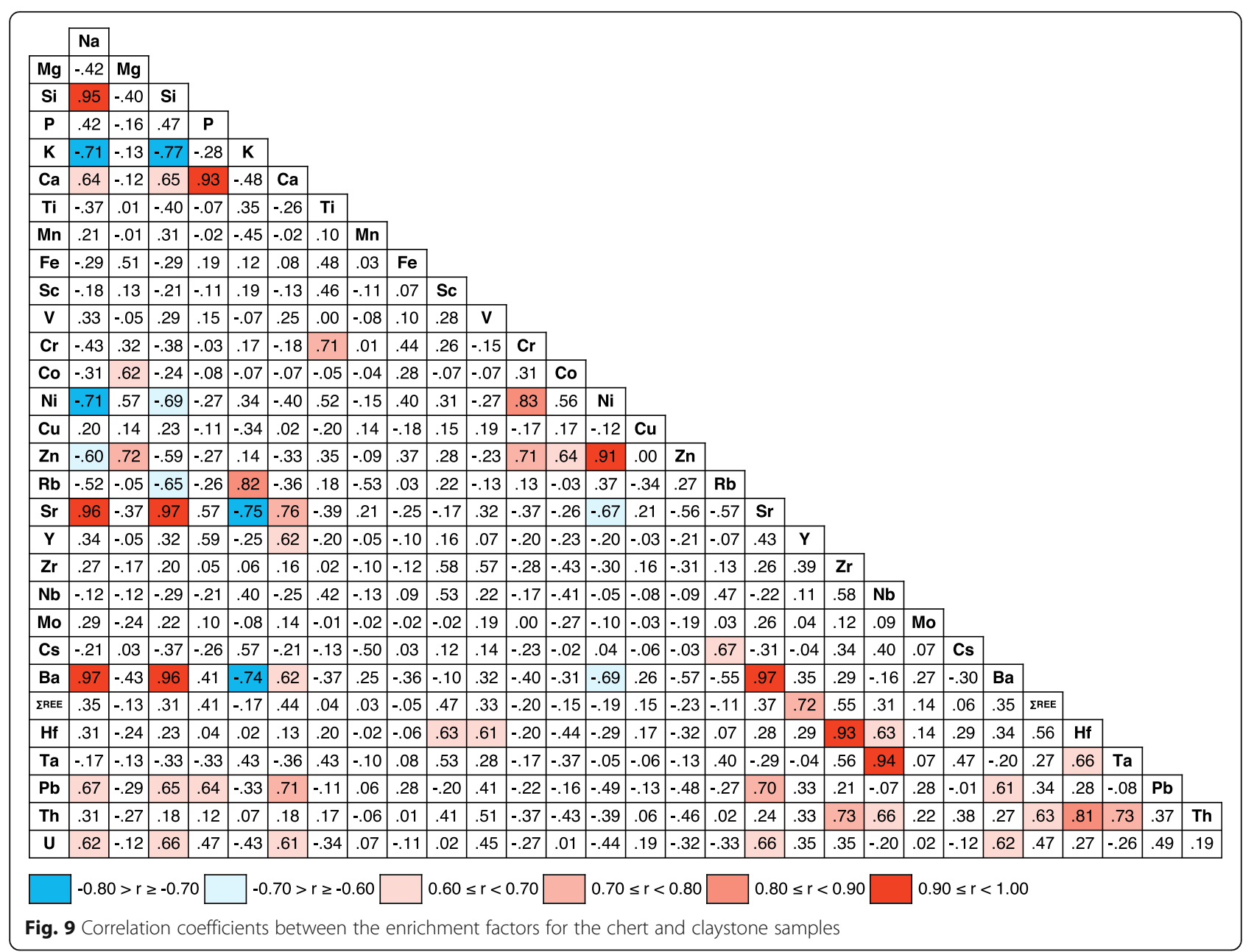

Panthalassa was also decreased during the E1 interval. We infer that the decimation of conodonts in this oceanic region was likely to have been related to the collapse of primary productivity. Following the resurgence in primary productivity after the E1 event, the biogenic apatite content proxies had recovered to pre-impact values by the first chert bed overlying the claystone layer, which suggests conodonts had begun to recover after the E1 event.

In contrast, radiolarian burial flux did not recover until the E2 event, which was $300 \mathrm{kyr}$ after the impact event (Onoue et al. 2016a). To account for the sustained reduction in the burial flux of radiolarian silica during the E1 and E2 events, the factors controlling radiolarian burial flux (e.g., availability of dissolved silica and seawater temperature; De Wever et al. 2014) are discussed below.

\subsection{Redox change}

Elements such as Mn, V, U, and Mo are useful to constrain ancient oceanic redox conditions (Tribovillard et al. 2006), because their valency can vary as a function of the prevailing redox potential (Calvert and Pedersen 1993; Calvert and Pedersen 2007). We discuss the sedimentary redox changes through the studied section using the following proxies for redox conditions.

Manganese is one of the most commonly used geochemical proxies for redox conditions in the oceanic environment. It forms insoluble $\mathrm{Mn}(\mathrm{III})$ or $\mathrm{Mn}(\mathrm{IV})$ hydroxides or oxides (e.g., $\mathrm{MnO}_{2}$ ) that are deposited rapidly in particulate form (Calvert and Pedersen 1993; Sholkovitz et al. 1994). However, under anoxic conditions, $\mathrm{Mn}$ is reduced to $\mathrm{Mn}$ (II) and forms soluble cations (e.g., $\mathrm{Mn}^{2+}$ and $\mathrm{MnCl}^{+}$). Consequently, a small enrichment factor for $\mathrm{Mn}\left(\mathrm{Mn}_{\mathrm{EF}}\right)$ in marine sediments suggests reducing depositional conditions near the surface of the sediments. In the studied section, $\mathrm{Mn}_{\mathrm{EF}}$ generally fluctuates $(0.55-1.95)$ around a UCC value of 1, except for several high- $\mathrm{Mn}_{\mathrm{EF}}$ peaks $\left(\mathrm{Mn}_{\mathrm{EF}}>2\right.$, Fig. 7). Although it is possible that these high- $\mathrm{Mn}_{\mathrm{EF}}$ peaks could reflect diagenetic enrichment of Mn, their origin remains unclear. Compared with the general trend of $\mathrm{Mn}_{\mathrm{EF}}$ in Upper Triassic bedded cherts in the Sakahogi section (Nozaki et al. 2019), the $\mathrm{Mn}_{\mathrm{EF}}$ values in the studied section are lower than the average value of the 

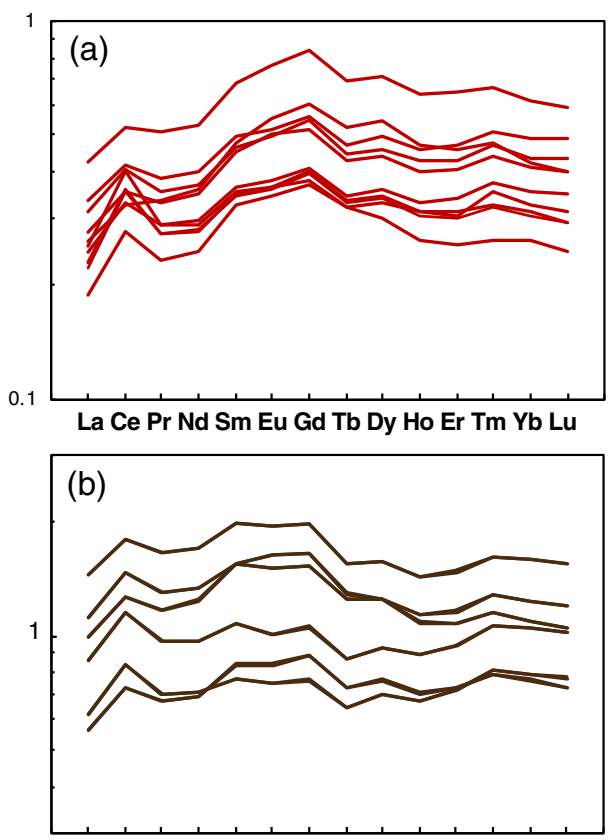

La Ce Pr Nd Sm Eu Gd Tb Dy Ho Er Tm Yb Lu

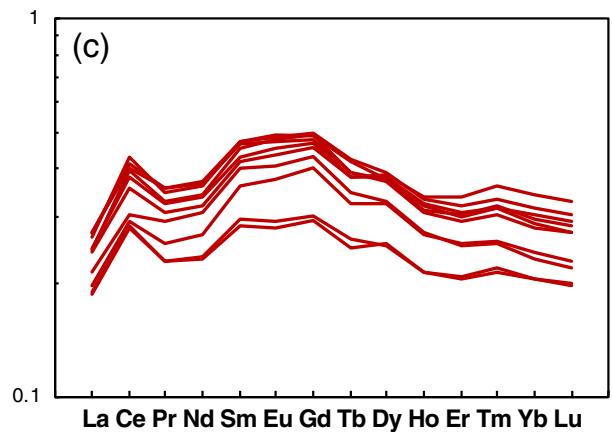

Fig. 10 UCC-normalized REE patterns of the chert and claystone samples. a Chert layers in the E2 interval, $\mathbf{b}$ claystone layers in the E1 interval, and $\mathbf{c}$ chert layers before the impact event

entire Norian Stage $\left(\mathrm{Mn}_{\mathrm{EF}}=3.00 ; n=35\right)$. However, significant redox changes across the ejecta layer cannot be recognized from Mn.

Vanadium and $U$ enrichments in sediments are useful proxies for reducing depositional conditions, ranging from moderately to strongly reducing (Sadiq 1988; Algeo and Maynard 2004; Tribovillard et al. 2006). Vanadium and $U$ reduction in seawater occurs under Eh conditions close to that required for the reduction of $\mathrm{Fe}(\mathrm{III})$ to $\mathrm{Fe}(\mathrm{II})$, which is lower than that for $\mathrm{Mn}$ reduction (Takeno 2005). In oxic seawater, V is present as soluble $\mathrm{V}(\mathrm{V})$ in the quasi-conservative form of vanadate oxyanions $\left(\mathrm{HVO}_{4}{ }^{2-}\right.$ and $\left.\mathrm{H}_{2} \mathrm{VO}_{4}{ }^{-}\right)$. When conditions change from oxic to mildly reducing, $\mathrm{V}(\mathrm{V})$ converts to $\mathrm{V}(\mathrm{IV})$ and forms the vanadyl ion $\left(\mathrm{VO}^{2+}\right)$, related hydroxyl species $\left(\mathrm{VO}(\mathrm{OH})_{3}{ }^{-}\right)$, and insoluble hydroxides $\left(\mathrm{VO}(\mathrm{OH})_{2}\right) \quad$ (Breit and Wanty 1991; Wanty and
Goldhaber 1992). Under such reducing conditions, soluble $\mathrm{U}(\mathrm{VI})$ is reduced to insoluble U(IV). In the studied section, $\mathrm{V}_{\mathrm{EF}}$ values show constant low values across the ejecta layer (0.88-1.67) and are similar to UCC values throughout the studied section (Fig. 7). $\mathrm{U}_{\mathrm{EF}}$ is higher than that of UCC, but its values are low (1.02-2.73) compared with $\mathrm{U}_{\mathrm{EF}}$ in modern anoxic-sulfidic basins ( 5; Algeo and Tribovillard 2009) and a period of anoxia in the Anisian reported from the Sakahogi section (Nozaki et al. 2019). The V and U data demonstrate that the redox conditions in the studied section were stable and oxic across the impact event. We further examined the redox conditions based on the enrichment of Mo, but $\mathrm{Mo}_{\mathrm{EF}}$ is constantly low or similar to UCC values in the studied section, except for one outlier at $90.0 \mathrm{~cm}$ (Fig. 7).

The Ce anomaly is also a common tracer for redox conditions in pelagic sediments (e.g., Kato et al. 2002; Fujisaki et al. 2016; Nozaki et al. 2019). Given that Ce is relatively insoluble in seawater following oxidation from $\mathrm{Ce}(\mathrm{III})$ to $\mathrm{Ce}(\mathrm{IV})$, it responds to redox changes in seawater (Sholkovitz et al. 1992). Authigenic carbonate and phosphate minerals are considered to record seawater REE chemistry (Toyoda and Tokonami 1990; Kamber and Webb 2001). However, in the studied section, the chert samples consist of a mixture of biogenic silica and detrital materials. Therefore, $\mathrm{Ce}_{\mathrm{EF}}$ in the chert samples may reflect both seawater and detrital components, whereas in the claystones could be dominated by components from detrital material rather than from seawater. $\mathrm{Ce} / \mathrm{Ce}^{*}$ values in the studied section range from 1.10 to 1.63 , and generally show a relatively constant value of $\sim 1.4$ (Fig. 11). The slightly positive Ce anomaly $\left(\mathrm{Ce} / \mathrm{Ce}^{*}>1\right)$ throughout the studied section could be attributable to the provenance of detrital components (discussed in next subsection), as reflected by the different $\mathrm{K} / \mathrm{Al}$ and $\mathrm{Rb} / \mathrm{Al}$ ratios as compared with average $\mathrm{UCC}$ (Fig. 5). Hence, our results suggest that $\mathrm{Ce} / \mathrm{Ce}$ * values of the studied section mainly record the detrital signature. However, the $\mathrm{Ce} / \mathrm{Ce}^{*}$ variation in this study is much narrower than that during the late Permian oceanic anoxia event (Kato et al. 2002) and the period of acidic conditions at the end-Triassic (Hori et al. 2007), which again implies that there was no significant redox change at this pelagic site due to the Late Triassic impact event.

Our analysis of redox-sensitive elements cannot detect any redox change in the equatorial region of the Panthalassa Ocean across the Late Triassic impact event. Redox conditions along the Panthalassan coast of the western Pangean supercontinent have been studied throughout the Upper Triassic to Lower Jurassic interval in the Black Bear Ridge section, British Columbia (Sephton et al. 2002; Wignall et al. 2007; Onoue et al. 2016b) (Fig. 2). The redox-sensitive 


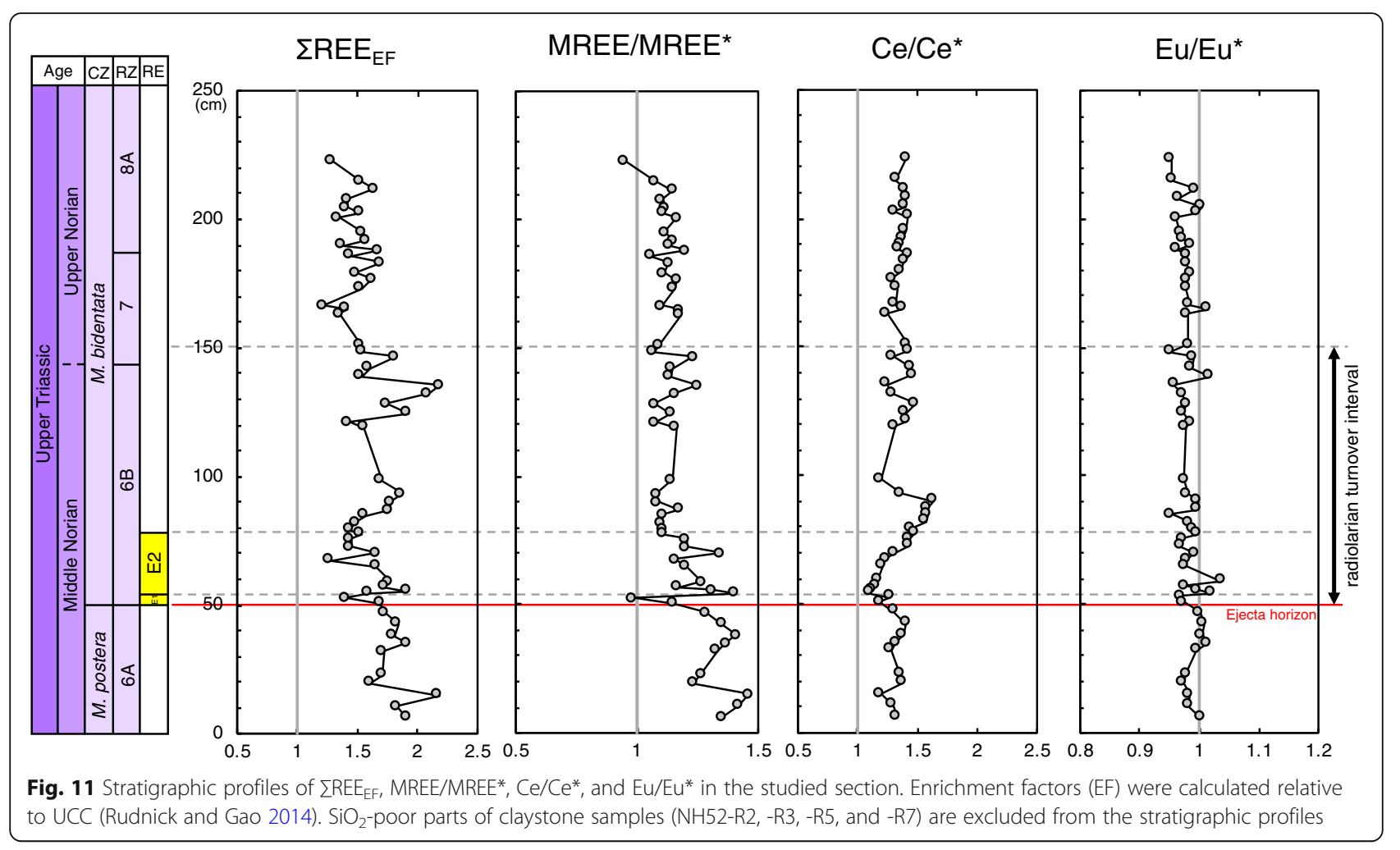

elements show there was no redox change in the middle to late Norian (Wignall et al. 2007). In the western Tethys Ocean, Upper Triassic carbonate sequences of the Lagonegro Basin, southern Italy (Fig. 2) have been examined for redox changes using Mo and $\mathrm{U}$ enrichments and $\mathrm{Ce} / \mathrm{Ce}^{*}$ anomalies. Redox changes in the middle to upper Norian interval have not been detected (Casacci et al. 2016). In summary, the Norian impact did not appear to induce redox changes in the Panthalassa and western Tethys oceans, although this interpretation requires further geochemical study at other middle to late Norian sites.

\subsection{Changes in dust provenance or hydrological cycle}

The HFS (Ti, Zr, Hf, Nb, and Ta) and alkali ( $\mathrm{K}$ and $\mathrm{Rb}$ ) elements are largely contained in detrital phases in the Triassic bedded chert sequences of the Inuyama area (Hori et al. 2000; Soda and Onoue 2019). These detrital components were transported to a pelagic setting in a low-latitude region of the Panthalassa Ocean (Uno et al. 2015), mainly as eolian dust or aerosols (Hori et al. 1993). According to model simulations of the surface winds (Kutzbach and Gallimore 1989), dust delivered to the depositional area of the bedded cherts in the Inuyama area largely originated from a low-latitudinal zone of western Pangea (Nakada et al. 2014; Ikeda et al. 2017) (Fig. 2).

The enrichments of HFS elements are relatively constant throughout the studied section and close to a UCC value of 1 . This suggests that UCC-like terrigenous material was the source for these elements throughout the whole section. Given that different terrestrial reservoirs have characteristic $\mathrm{Zr} / \mathrm{Hf}$ and $\mathrm{Nb} / \mathrm{Ta}$ ratios, and there is no significant fractionation of these ratios by continental weathering or sedimentation processes, $\mathrm{Nb} / \mathrm{Ta}$ and $\mathrm{Zr}$ / Hf can be used to constrain the source of these elements in sediments (Pfänder et al. 2007; Berndt et al. 2011). In the Sakahogi section, both the chert and claystone samples have typical UCC ratios (Pfänder et al. 2007), with $\mathrm{Zr} / \mathrm{Hf}=40.1 \pm 1.9$ (chert; $n=57$ ) and $39.5 \pm 2.4$ (claystone; $n=6)$, and $\mathrm{Nb} / \mathrm{Ta}=14.5 \pm 0.4$ and $14.4 \pm 0.2$ (Table 2), respectively. In addition, $\mathrm{Zr} / \mathrm{Hf}$ and $\mathrm{Nb} / \mathrm{Ta}$ values in the Sakahogi section show a strong linear correlation $\left(R^{2}>0.99\right.$, Fig. 6) compared with the values in modern deep-sea sediments (e.g., Plank and Langmuir 1998). These data suggest that typical UCC-like terrigenous material was the principal detrital components throughout the Sakahogi section. Alternatively, if the values of $\mathrm{Zr} / \mathrm{Hf}$ and $\mathrm{Nb} / \mathrm{Ta}$ were similar in wide area of hinterland in Pangea, the potential change in provenance of eolian dust cannot be ruled out. Actually, changes in dust provenance that occurred during Norian in Fundy 
Basin, North America, are suggested based on reappearance of eolian deposits on various timescale (Kent and Olsen 2000). Notably, the lower sublayer claystone (NH52-R2) exhibits lower $\mathrm{Zr}_{\mathrm{EF}}, \mathrm{Hf}_{\mathrm{EF}}, \mathrm{Nb}_{\mathrm{EF}}$, and $\mathrm{Ta}_{\mathrm{EF}}$, and higher $\mathrm{Ti}_{\mathrm{EF}}$ than those of the other upper claystone samples and cherts. This is most likely explained by contamination of ejecta materials in the lower sublayer.

Concentrations of $\mathrm{K}$ and $\mathrm{Rb}$ correlate well with those of $\mathrm{Al}$ and HFS elements, which indicate that these alkali elements are of terrigenous origin. Potassium, $\mathrm{Rb}$, and $\mathrm{Al}$ contents are attributed to aluminosilicates, especially clay minerals. Given that $\mathrm{Al}$ is resistant to chemical weathering (Nesbitt and Young 1982), Al-normalized $\mathrm{K}$ and $\mathrm{Rb}$ can be used as chemical weathering indicators (Tanaka and Watanabe 2015; Grygar et al. 2019; Liu et al. 2019). In the present study, the enrichment factors of $\mathrm{K}$ and $\mathrm{Rb}$ show similar trends. The stratigraphic variations in $\mathrm{K}_{\mathrm{EF}}$ and $\mathrm{Rb}_{\mathrm{EF}}$ show an obvious decreasing trend during the E2 event (Fig. 8), which suggest the intensity of aluminosilicate chemical weathering increased during the E2 event.

To assess the degree of chemical weathering in hinterland regions using major elements, we calculated the Chemical Index of Alteration (CIA; Nesbitt and Young 1982). Values of CIA predict the extent of decomposition of feldspar minerals, which are the most abundant mineral group in the UCC. Before calculating CIA values, apatite-derived $\mathrm{CaO}$ concentrations were corrected using the procedure of Price and Velbel (2003). This correction estimates $\mathrm{CaO}$ in the silicate phase $\left(\mathrm{CaO}^{*}\right)$ by subtracting $\mathrm{CaO}$ in the phosphate phase predicted from the $\mathrm{P}_{2} \mathrm{O}_{5}$ concentration and stoichiometry of apatite:

$$
\mathrm{CaO}^{*}=\operatorname{molCaO}-\left[(10 / 3) \times \mathrm{molP}_{2} \mathrm{O}_{5}\right]
$$

CIA was then calculated as:

$$
\mathrm{CIA}^{*}=\mathrm{Al}_{2} \mathrm{O}_{3} /\left(\mathrm{Al}_{2} \mathrm{O}_{3}+\mathrm{Na}_{2} \mathrm{O}+\mathrm{K}_{2} \mathrm{O}+\mathrm{CaO} *\right) \times 100
$$

CIA values vary between $75-82$ in the studied section (Fig. 8). CIA values are relatively constant below the ejecta layer, slightly decrease in the E1 interval, and then increase in the E2 interval (especially in sample for NHR48). These stratigraphic variations in CIA values indicate intensified chemical weathering on continents during the E2 interval, implying that the climate changed to relatively warm and humid conditions after the impact event. $K_{E F}$ and $R b_{E F}$ values decrease with increasing CIA values, indicating that $\mathrm{K}$ and $\mathrm{Rb}$ were released from primary minerals, possibly micas and feldspars in felsic rocks, during continental chemical weathering. Another possibility is that the increased CIA in the E2 interval might have reflected a change in dust provenance associated with a shift in regional precipitation pattern. If a precipitation decreased in a previously wet (i.e., intensively weathered) region, the region could become a new source of high CIA dust to the Sakahogi section. However, if that was the case, the direction and intensity of prevailing winds, or the atmospheric circulation pattern, could have also changed, as well as the changes in dust provenance and hydrological cycle. Thus, this scenario should be carefully evaluated by further investigations for other marine and terrestrial records of the corresponding period.

The low-latitudinal zone of western Pangea might have been the major source of detrital elements to the deep-sea sediments of the equatorial Panthalassa (Nakada et al. 2014; Ikeda et al. 2015). Sedimentological studies in this region (e.g., the Petrified Forest National Park in Arizona) suggest an arid to semi-arid climate with significant seasonality during the Norian (Prochnow et al. 2006; Cleveland et al. 2007). However, the mean annual precipitation (MAP) inferred from a geochemical weathering index (the chemical index of alteration minus potassium index; Nordt et al. 2015) from the Chinle Formation in the Petrified Forest National Park (Fig. 2) suggests that short-term wetter periods could have occurred in the middle Norian (218-213 Ma; Ramezani et al. 2011; Ramezani et al. 2014). According to the age model of Nordt et al. (2015), these middle Norian climate shifts occurred close to the time of formation of the Manicouagan impact crater at $215.5 \mathrm{Ma}$ (Jaret et al. 2018). A palynological record from the Chinle Formation (Baranyi et al. 2017) also demonstrated that gradual aridification during the Norian was interrupted by at least two short-lived wetter climatic periods in the middle Norian, as inferred from an increase in hygrophyte vegetation. Given that the timing of this vegetation change in a wetter climatic period is very close to the age range of the Manicouagan impact event, Baranyi et al. (2017) suggested that the impact might have contributed to the vegetation change.

These studies have shown that the Manicouagan impact event might have coincided with middle Norian climate and vegetation changes during a short-lived wet period, which is consistent with our results showing intensified chemical weathering of the hinterland for $\sim 300$ kyr after the impact event. However, in the case of the Chicxulub impact event at the Cretaceous-Paleogene boundary, the environmental effects of climatically active gases (e.g., sulfur (di)oxide and carbon dioxide) released from the impact site were short-lived (years to hundreds of years; Artemieva et al. 2017), and cannot explain such a relatively long-term $(\sim 300 \mathrm{kyr})$ duration of intensified chemical weathering. The existing data imply no direct 
causality between the Manicouagan impact event and the change to a wetter climate. However, the change to a warm, humid climate is an important factor in considering the controls on radiolarian burial flux, which will be discussed in the following section.

\subsection{Decline of radiolarian burial flux}

The E1 event is considered to have lasted $10^{4}-10^{5}$ years after the impact event, based on Os isotope studies (Sato et al. 2013; Onoue et al. 2016a). Our geochemical data demonstrate that this interval represents the duration required for the restoration of burial flux by primary and silica- and apatite-secreting organisms after the middle Norian impact. A decline in radiolarian and conodont burial flux during the E1 event might be explained by the post-impact shutdown of primary productivity as discussed above. Our data also reveal that primary productivity and conodont burial flux had recovered to preimpact values by the beginning of the E2 event. However, radiolarian burial flux did not recover until the E2 event, which was $\sim 300 \mathrm{kyr}$ after the impact (Onoue et al. 2016a). The mass accumulation rates (MAR) of radiolarian silica decreased from 0.1 to $0.02 \mathrm{~g} \mathrm{~cm}^{-2} \mathrm{kyr}^{-1}$ across the impact and continued to decrease during the E2 interval (Fig. 3a).

Previous studies have suggested that radiolarian abundance is mainly controlled by the availability of dissolved silica and variations of temperature in the surface water (Anderson et al. 1989; Abelmann and Gowing 1996; Boltovskoy et al. 2010; De Wever et al. 2014). Recently, Ikeda et al. (2017) suggested that the burial flux of biogenic silica (BSi) over a time scale longer than the residence time of dissolved silica in the ocean (generally < $100 \mathrm{kyr}$ for the Phanerozoic) can be proportional to the silica input flux to the ocean that is controlled by global continental silicate weathering flux. Thus, the decline of radiolarian burial flux for $\sim 300 \mathrm{kyr}$ after the impact might be explained by suppressed continental silicate weathering. However, this is inconsistent with the inferred climatic changes toward a wetter condition and enhanced weathering in Pangea discussed above. In addition, MAR of radiolarian silica during the E2 event was an order of magnitude lower than the calculated BSi burial flux for the middle Norian (Ikeda et al. 2017). This discrepancy also suggests a fundamental gap between our observation and a simple mass balance model of oceanic dissolved silica during the E2 event, though we need further investigation to confirm the temporal variations in the radiolarian burial flux with a reliable sedimentation rate for the middle Norian chert. Changes in dissolved silica concentrations are also not sufficient to explain the decline of radiolarian silica burial flux during the E1 and E2 events, because silica-saturated conditions $\left(\geq 110 \mathrm{mg} / \mathrm{L} \mathrm{SiO}_{2}\right)$ with respect to biogenic silica presumably existed in the Late Triassic (Racki and Cordey 2000; Grenne and Slack 2003). Furthermore, $\mathrm{Si}_{\mathrm{EF}}$ during the E2 event is comparable to that in the other intervals before and after the impact, implying no significant change in the availability of silica in the studied section (Fig. 7). The $\delta^{13} C_{\text {org }}$ data suggest there was a resurgence in primary productivity after the E1 event (Fig. 3a, Onoue et al., 2016a). However, the recovery of radiolarian burial flux was significantly delayed (Fig. 3a). Taking these into consideration, other factors such as sea surface temperature must be invoked to account for the sustained reduction in the burial flux of radiolarian silica.

Relatively little information is available regarding the effects of seawater temperature variations on living radiolarians (Anderson et al. 1989; Anderson et al. 1990; Matsuoka and Anderson 1992). Experimental and observational studies have shown that the mean longevity and growth rate decrease markedly when temperature is raised. For example, laboratory culturing data for three tropical and subtropical radiolarian taxa (Spongaster tetras, Didymocyrtis tetrathalamus, and Dictyornyne truncatum) suggest that the maximum growth and longevity (mean longevity of 22-23 days) are achieved at a temperate condition of $21-28{ }^{\circ} \mathrm{C}$, but skeletal growth and survival were remarkably suppressed at temperatures above $32{ }^{\circ} \mathrm{C}$ (longevity of 2 days), and no individuals survived at temperatures above $36{ }^{\circ} \mathrm{C}$ (Anderson et al. 1989; Anderson et al. 1990; Matsuoka and Anderson 1992). Furthermore, kinetic studies have shown that an increased temperature is the major factor that affects silica dissolution rates in the ocean (Erez et al. 1982; Ragueneau et al. 2000), which might enhance the in situ dissolution of radiolarian opal in surface waters.

Even if Norian radiolarians had different temperature tolerances, the consequences of climate warming would have affected the production of radiolarian opal in the near-surface waters. Our weathering proxy data $\left(\mathrm{K}_{\mathrm{EF}}\right.$, $\mathrm{Rb}_{\mathrm{EF}}$, and CIA values) suggest acceleration of the hydrological cycle and an increase in continental chemical weathering rates, which is consistent with a greenhouse climate (e.g., Knobbe and Schaller 2018). Thus, we interpret that radiolarian silica burial flux did not recover until the E2 event due to an increased sea surface temperature. This interpretation is speculative-the existing data are unable to prove direct causality between greenhouse climate and the impact event, and the sea surface temperatures during the E1 and E2 events have yet to be determined by conodont $\delta^{18} \mathrm{O}_{\text {apatite }}$ data (e.g., Rigo and Joachimski 2010; Rigo et al. 2012; Trotter et al. 2015; Knobbe and Schaller 2018). Furthermore, relationships to other environmental factors related to biogenic opal production, such as dissolved $\mathrm{Al}$ concentrations and microbial degradation of organic 
matter (e.g., Van Bennekom et al. 1988; Nelson et al. 1995; Bidle and Azam 1999; Ragueneau et al. 2000), must be considered.

\section{Conclusions}

Stratigraphic profiles of major, trace, and rare earth elements in middle to upper Norian (Late Triassic) bedded cherts of the Mino Belt, central Japan, were constructed in order to assess the environmental changes that triggered a decline in radiolarian burial flux in the Panthalassa Ocean after the Norian impact event. Based on our geochemical data, paleoenvironmental changes across the Norian impact event can be summarized as follows.

1. Productivity and burial flux estimates based on $\delta^{13} C_{\text {org }}$ values and enrichments of $\mathrm{Ba}, \mathrm{Ca}, \mathrm{P}$, and REEs suggest that there was a post-impact shutdown of productivity by primary and silica- and apatite-secreting organisms. Primary productivity and biogenic apatite (i.e., conodont) burial flux had recovered to pre-impact levels $10^{4}-10^{5}$ years after the impact event, but radiolarian burial flux did not recover for $\sim 300 \mathrm{kyr}$ after the impact.

2. Redox-sensitive elements ( $\mathrm{Mn}, \mathrm{V}, \mathrm{U}$, and $\mathrm{Mo}$ ) and $\mathrm{Ce} / \mathrm{Ce}^{*}$ anomalies exhibit limited fluctuations throughout the studied section, which indicate that there was no significant redox change in the pelagic realm of the Panthalassa Ocean across the Late Triassic impact event. Therefore, the change in redox conditions was not related to the decrease in radiolarian burial flux after the impact.

3. Weathering proxies, such as CIA values and enrichments of $\mathrm{K}$ and $\mathrm{Rb}$, suggest that intense chemical weathering of the hinterland occurred during the decline in radiolarian burial flux after the Norian impact event. A short-lived wet period near the time of the Norian impact has been documented from the low-latitudinal zone of the western Pangean region (e.g., the Petrified Forest National Park in Arizona), which might have been the major source of detrital elements in the studied section. These data appear to reflect acceleration of the hydrological cycle and an increase in continental chemical weathering rates, which might have been induced by a greenhouse climate after the impact.

4. Radiolarian burial flux did not recover for $\sim 300 \mathrm{kyr}$ after the impact. We hypothesize that radiolarian burial flux decreased in response to an increased sea surface temperature due to a greenhouse climate, but this needs to be verified by independent data (e.g., conodont $\delta^{18} \mathrm{O}_{\text {apatite }}$ ).

\section{Abbreviations}

PGE: Platinum group element; UCC: Upper continental crust; REE: Rare earth element; LREE: Light rare earth element; MREE: Middle rare earth element; HREE: Heavy rare earth element; CIA: Chemical Index of Alteration; MAP: Mean annual precipitation; MAR: Mass accumulation rates

\section{Acknowledgements}

We are grateful to $Y$. Itabashi and C. Kabashima for their assistance with sample preparation and chemical analyses at the University of Tokyo. K. Soda and D. Yamashita assisted with fieldwork and sample collection. Y. Isozaki, an anonymous reviewer and the editor, $\mathrm{H}$. Kawahata are also thanked for their careful constructive reviews and editorial handling.

\section{Authors' contributions}

$H S, K Y, T O$, and YK designed this study. HS, YT, KY, KF, and TO performed the geochemical analyses. All authors participated in the discussions to interpret the analytical results and aided in the writing of the manuscript. All authors read and approved the final manuscript.

\section{Funding}

This work was supported by the Japan Society for the Promotion of Science, Grant Numbers 15J30004 and 17K14409 to HS, 17 H02975 to TO, and $15 \mathrm{H} 05771$ to $\mathrm{YK}$.

\section{Availability of data and materials}

Please contact the corresponding author regarding data requests.

\section{Competing interests}

The authors declare that they have no competing interest.

\section{Author details}

'Ocean Resources Research Center for Next Generation, Chiba Institute of Technology, 2-17-1 Tsudanuma, Narashino, Chiba 275-0016, Japan. ${ }^{2}$ Submarine Resources Research Center, Research Institute for Marine Resources Utilization, Japan Agency for Marine-Earth Science and Technology, 2-15 Natsushima-cho, Yokosuka, Kanagawa 237-0061, Japan. ${ }^{3}$ Faculty of Science and Engineering, Waseda University, 3-4-1 Okubo, Shinjuku-ku, Tokyo 169-8555, Japan. ${ }^{4}$ Frontier Research Center for Energy and Resources, School of Engineering, The University of Tokyo, 7-3-1 Hongo, Bunkyo-ku, Tokyo 113-8656, Japan. ${ }^{5}$ Department of Systems Innovation, School of Engineering, The University of Tokyo, 7-3-1 Hongo, Bunkyo-ku, Tokyo 113-8656, Japan. ${ }^{6}$ Department of Earth and Planetary Sciences, Kyushu University, 744 Motooka, Nishi-ku, Fukuoka 819-0395, Japan.

Received: 5 February 2020 Accepted: 4 September 2020

Published online: 07 October 2020

\section{References}

Abelmann A, Gowing MM (1996) Horizontal and vertical distribution pattern of living radiolarians along a transect from the Southern Ocean to the South Atlantic subtropical region. Deep-Sea Res Part I 43:361-382. https://doi.org/ 10.1016/0967-0637(96)00003-9

Algeo TJ, Ingall E (2007) Sedimentary $C_{\text {org: }}$ P ratios, paleocean ventilation, and Phanerozoic atmospheric $\mathrm{pO}_{2}$. Palaeogeogr Palaeoclimatol Palaeoecol 256: 130-155. https://doi.org/10.1016/j.palaeo.2007.02.029

Algeo TJ, Kuwahara K, Sano H, Bates S, Lyons T, Elswick E, Hinnov L, Ellwood B, Moser J, Maynard JB (2011) Spatial variation in sediment fluxes, redox conditions, and productivity in the Permian-Triassic Panthalassic Ocean. Palaeogeogr Palaeoclimatol Palaeoecol 308:65-83. https://doi.org/10.1016/j. palaeo.2010.07.007

Algeo TJ, Maynard JB (2004) Trace-element behavior and redox facies in core shales of Upper Pennsylvanian Kansas-type cyclothems. Chem Geol 206:289318. https://doi.org/10.1016/j.chemgeo.2003.12.009

Algeo TJ, Tribovillard N (2009) Environmental analysis of paleoceanographic systems based on molybdenum-uranium covariation. Chem Geol 268:211225. https://doi.org/10.1016/j.chemgeo.2009.09.001

Anderson OR, Bennett P, Bryan M (1989) Experimental and observational studies of radiolarian physiological ecology: 3. Effects of temperature, salinity and light intensity on the growth and survival ofSpongaster tetras tetras maintained in laboratory culture. Mar Micropaleontol 14:275-282. https://doi. org/10.1016/0377-8398(89)90014-5 
Anderson OR, Bryan M, Bennett P (1990) Experimental and observational studies of radiolarian physiological ecology: 4 . Factors determining the distribution and survival ofDidymocyrtis tetrathalamus tetrathalamus with implications for paleoecological interpretations. Mar Micropaleontol 16:155-167. https://doi. org/10.1016/0377-8398(90)90001-3

Ando A, Kodama K, Kojima S (2001) Low-latitude and Southern Hemisphere origin of Anisian (Triassic) bedded chert in the Inuyama area, Mino terrane, central Japan. J Geophys Res Solid Earth 106:1973-1986. https://doi.org/10. 1029/2000JB900305

Artemieva N, Morgan J, Expedition 364 Science Party (2017) Quantifying the release of climate-active gases by large meteorite impacts with a case study of Chicxulub. Geophys Res Lett 44:10180-10188. https://doi.org/10.1002/ 2017GL074879

Baranyi V, Reichgelt T, Olsen PE, Parker WG, Kürschner WM (2017) Norian vegetation history and related environmental changes: New data from the Chinle Formation, Petrified Forest National Park (Arizona, SW USA). Geol Soc Am Bull 130:775-795. https://doi.org/10.1130/B31673.1

Berndt J, Deutsch A, Schulte P, Mezger K (2011) The Chicxulub ejecta deposit at Demerara Rise (western Atlantic): dissecting the geochemical anomaly using laser ablation-mass spectrometry. Geology 39:279-282. https://doi.org/10. 1130/G31599.1

Bidle KD, Azam F (1999) Accelerated dissolution of diatom silica by marine bacterial assemblages. Nature 397:508-512. https://doi.org/10.1038/17351

Bishop JKB (1988) The barite-opal-organic carbon association in oceanic particulate matter. Nature 332:341-343. https://doi.org/10.1038/ $332341 \mathrm{a} 0$

Boltovskoy D, Kling SA, Takahashi K, Bjørklund KR (2010) World atlas of distribution of recent Polycystina (Radiolaria). Palaeontol Electron 13:1-229

Breit GN, Wanty RB (1991) Vanadium accumulation in carbonaceous rocks: a review of geochemical controls during deposition and diagenesis. Chem Geol 91:83-97. https://doi.org/10.1016/0009-2541(91)90083-4

Calvert SE, Pedersen TF (1993) Geochemistry of recent oxic and anoxic marine sediments: implications for the geological record. Mar Geol 113:67-88. https://doi.org/10.1016/0025-3227(93)90150-T

Calvert SE, Pedersen TF (2007) Chapter fourteen elemental proxies for palaeoclimatic and palaeoceanographic variability in marine sediments: interpretation and application. In: Hillaire-Marcel C, Vernal AD (eds) Developments in Marine Geology, vol 1. Elsevier, pp 567-644. https://www. sciencedirect.com/science/article/pii/S1572548007010196

Casacci M, Bertinelli A, Algeo TJ, Rigo M (2016) Carbonate-to-biosilica transition at the Norian-Rhaetian boundary controlled by rift-related subsidence in the western Tethyan Lagonegro Basin (southern Italy). Palaeogeogr Palaeoclimatol Palaeoecol 456:21-36. https:/doi.org/10.1016/j.palaeo.2016.05.007

Chen J, Algeo TJ, Zhao L, Chen Z-Q, Cao L, Zhang L, Li Y (2015) Diagenetic uptake of rare earth elements by bioapatite, with an example from Lower Triassic conodonts of South China. Earth-Sci Rev 149:181-202. https://doi.org/ 10.1016/j.earscirev.2015.01.013

Cleveland DM, Atchley SC, Nordt LC (2007) Continental sequence stratigraphy of the Upper Triassic (Norian-Rhaetian) Chinle Strata, Northern New Mexico, U. S.A.: Allocyclic and Autocyclic Origins of Paleosol-Bearing Alluvial Successions. J Sed Res 77:909-924. https://doi.org/10.2110/jsr.2007.082

Clutson MJ, Brown DE, Tanner LH (2018) Distal processes and effects of multiple Late Triassic terrestrial bolide impact: Insights from the Norian Manicouagan event, Northeastern Quebec, Canada. In: Tanner LH (ed) Topics in Geobiology, vol 46. Springer, pp 127-188. https://link.springer.com/chapter/1 0.1007/978-3-319-68009-5_5

De Wever P, O'Dogherty L, Gorican S (2014) Monsoon as a cause of radiolarite in the Tethyan realm. Compt Rend Geosci 346:287-297. https://doi.org/10.1016/ j.crte.2014.10.001

Dehairs F, Chesselet R, Jedwab J (1980) Discrete suspended particles of barite and the barium cycle in the open ocean. Earth Planet Sci Lett 49:528-550. https://doi.org/10.1016/0012-821X(80)90094-1

Dymond J, Collier R (1996) Particulate barium fluxes and their relationships to biological productivity. Deep Sea Research Part II: Top Stud Oceanogr 43: 1283-1308. https://doi.org/10.1016/0967-0645(96)00011-2

Erez J, Takahashi K, Honjo S (1982) In-situ dissolution experiment of Radiolaria in the central North Pacific Ocean. Earth Planet Sci Lett 59:245-254. https://doi. org/10.1016/0012-821X(82)90129-7

Fujisaki W, Sawaki Y, Yamamoto S, Sato T, Nishizawa M, Windley BF, Maruyama S (2016) Tracking the redox history and nitrogen cycle in the pelagic Panthalassic deep ocean in the Middle Triassic to Early Jurassic: Insights from redox-sensitive elements and nitrogen isotopes. Palaeogeogr Palaeoclimatol Palaeoecol 449:397-420. https://doi.org/10.1016/j.palaeo.2016.01.039

German CR, Elderfield H (1989) Rare earth elements in Saanich Inlet, British Columbia, a seasonally anoxic basin. Geochim Cosmochim Acta 53:25612571. https://doi.org/10.1016/0016-7037(89)90128-2

German CR, Elderfield H (1990) Application of the Ce anomaly as a paleoredox indicator: the ground rules. Paleoceanogr 5:823-833. https://doi.org/10.1029/ PA005i005p00823

Grenne T, Slack JF (2003) Paleozoic and Mesozoic silica-rich seawater: Evidence from hematitic chert (jasper) deposits. Geology 31:319-322 doi: 10.1130/ 0091-7613(2003)031<0319:PAMSRS>2.0.CO:2

Grygar TM, Mach K, Martinez M (2019) Checklist for the use of potassium concentrations in siliciclastic sediments as paleoenvironmental archives. Sed Geol 382:75-84. https://doi.org/10.1016/j.sedgeo.2019.01.010

Hollis CJ (2003) The Cretaceous/Tertiary boundary event in New Zealand: profiling mass extinction. New Zealand J Geol Geophys 46:307-321. https:// doi.org/10.1080/00288306.2003.9515011

Hollis CJ, Rodgers KA, Strong CP, Field BD, Rogers KM (2003) Paleoenvironmental changes across the Cretaceous/Tertiary boundary in the northern Clarence valley, southeastern Marlborough, New Zealand. New Zealand J Geol Geophys 46:209-234. https://doi.org/10.1080/00288306.2003.9515005

Holser WT (1997) Evaluation of the application of rare-earth elements to paleoceanography. Palaeogeogr Palaeoclimatol Palaeoecol 132:309-323. https://doi.org/10.1016/S0031-0182(97)00069-2

Hori RS, Cho CF, Umeda H (1993) Origin of cyclicity in Triassic-Jurassic radiolarian bedded cherts of the Mino accretionary complex from Japan. The Island Arc 2:170-180. https://doi.org/10.1111/j.1440-1738.1993.tb00084.x

Hori RS, Fujiki T, Inoue E, Kimmura J-I (2007) Platinum group element anomalies and bioevents in the Triassic-Jurassic deep-sea sediments of Panthalassa. Palaeogeogr Palaeoclimatol Palaeoecol 244:391-406. https://doi.org/10.1016/ j.palaeo.2006.06.038

Hori RS, Higuchi Y, Fujiki T (2000) Chemical compositions and their environmental records of bedded cherts from acrretionary complexes in Japan. Memoir Geol Soc Jpn 55:43-59

Ikeda M, Hori RS, Okada Y, Nakada R (2015) Volcanism and deep-ocean acidification across the end-Triassic extinction event. Palaeogeogr Palaeoclimatol Palaeoecol 440:725-733. https://doi.org/10.1016/j.palaeo.2015. 09.046

Ikeda M, Tada R, Ozaki K (2017) Astronomical pacing of the global silica cycle recorded in Mesozoic bedded cherts. Nat Commun 8:15532. https://doi.org/ 10.1038/ncomms 15532

Imai N, Terashima S, Itoh S, Ando A (1995) 1994 compilation of analytical data for minor and trace elements in seventeen GSJ geochemical reference samples, "Igneous rock series". Geostand Newslett 19:135-213. https://doi.org/10.1111/ j.1751-908X.1995.tb00158.x

Isozaki Y (2014) Memories of Pre-Jurassic lost oceans: how to retrieve them from extant lands. Geosci Canada 41:283-311. https://doi.org/10.12789/geocanj. 2014.41.050

Jaret SJ, Hemming SR, Rasbury ET, Thompson LM, Glotch TD, Ramezani J, Spray JG (2018) Context matters - Ar-Ar results from in and around the Manicouagan Impact Structure, Canada: Implications for martian meteorite chronology. Earth Planet Sci Lett 501:78-89. https://doi.org/10.1016/j.epsl. 2018.08.016

Kamber BS, Webb GE (2001) The geochemistry of late Archaean microbial carbonate: implications for ocean chemistry and continental erosion history. Geochim Cosmochim Acta 65:2509-2525. https://doi.org/10.1016/S00167037(01)00613-5

Kato Y, Fujinaga K, Suzuki K (2005) Major and trace element geochemistry and Os isotopic composition of metalliferous umbers from the Late Cretaceous Japanese accretionary complex. Geochem Geophys Geosyst 6. https://doi. org/10.1029/2005GC000920

Kato Y, Fujinaga K, Suzuki K (2011) Marine Os isotopic fluctuations in the early Eocene greenhouse interval as recorded by metalliferous umbers from a Tertiary ophiolite in Japan. Gond Res 20:594-607. https://doi.org/10.1016/j.gr. 2010.12.007

Kato Y, Nakao K, Isozaki Y (2002) Geochemistry of Late Permian to Early Triassic pelagic cherts from southwest Japan: implications for an oceanic redox change. Chem Geol 182:15-34. https://doi.org/10.1016/S0009-2541(01)00273-X

Kato Y, Ohta I, Tsunematsu T, Watanabe Y, Isozaki Y, Maruyama S, Imai N (1998) Rare earth element variations in mid-Archean banded iron formations: Implications for the chemistry of ocean and continent and plate tectonics. 
Geochim Cosmochim Acta 62:3475-3497. https://doi.org/10.1016/500167037(98)00253-1

Kent DV, Olsen PE (2000) Magnetic polarity stratigraphy and paleolatitude of the Triassic-Jurassic Blomidon Formation in the Fundy Basin (Canada): implications for early Mesozoic tropical climate gradients. Earth Planet Sci Lett 179:311-324. https://doi.org/10.1016/S0012-821X(00)00117-5

Knobbe TK, Schaller MF (2018) A tight coupling between atmospheric $p \mathrm{CO}_{2}$ and sea-surface temperature in the Late Triassic. Geology 46:43-46. https://doi. org/10.1130/G39405.1

Kutzbach JE, Gallimore RG (1989) Pangaean climates: Megamonsoons of the megacontinent. J Geophys Res Atmospheres 94:3341-3357. https://doi.org/ 10.1029/JD094iD03p03341

Liu D, Zhang C, Yang D, Pan Z, Kong X, Huang Z, Wang J, Song Y (2019) Petrography and geochemistry of the Lopingian (upper Permian)Lower Triassic strata in the southern Junggar and Turpan basins, NW China: implications for weathering, provenance, and palaeogeography. Int Geol Rev 61:1016-1036. https://doi.org/10.1080/ 00206814.2018.1490932

Lu Y, Makishima A, Nakamura E (2007) Coprecipitation of Ti, Mo, Sn and Sb with fluorides and application to determination of $\mathrm{B}, \mathrm{Ti}, \mathrm{Zr}, \mathrm{Nb}, \mathrm{Mo}, \mathrm{Sn}, \mathrm{Sb}, \mathrm{Hf}$ and Ta by ICP-MS. Chem Geol 236:13-26. https://doi.org/10.1016/j.chemgeo.2006. 08.007

Makishima A, Nakamura E (2006) Determination of major, minor and trace elements in silicate samples by ICP-QMS and ICP-SFMS applying isotope dilution-internal standardisation (ID-IS) and multi-stage internal standardisation. Geostand Geoanal Res 30:245-271. https://doi.org/10.1111/j. 1751-908X.2006.tb01066.X

Matsuda T, Isozaki Y (1991) Well-documented travel history of Mesozoic pelagic chert in Japan: from remote ocean to subduction zone. Tectonics 10:475499. https://doi.org/10.1029/90TC02134

Matsuoka A, Anderson OR (1992) Experimental and observational studies of radiolarian physiological ecology: 5. Temperature and salinity tolerance of Dictyocoryne truncatum. Mar Micropaleontol 19:299-313. https://doi.org/10. 1016/0377-8398(92)90035-1

McManus J, Berelson WM, Klinkhammer GP, Johnson KS, Coale KH, Anderson RF, Kumar N, Burdige DJ, Hammond DE, Brumsack HJ, McCorkle DC, Rushdi A (1998) Geochemistry of barium in marine sediments: implications for its use as a paleoproxy. Geochim Cosmochim Acta 62:3453-3473. https://doi.org/10. 1016/S0016-7037(98)00248-8

Murray RW (1994) Chemical criteria to identify the depositional environment of chert: general principles and applications. Sed Geol 90:213-232. https://doi. org/10.1016/0037-0738(94)90039-6

Murray RW, Buchholtz ten Brink MR, Gerlach DC, Price Russ IIIG, Jones DL (1992) Interoceanic variation in the rare earth, major, and trace alement depositional chemistry of chert: Perspectives gained from the DSDP and ODP record. Geochim Cosmochim Acta 56:1897-1913. https://doi.org/10. 1016/0016-7037(92)90319-E

Murray RW, Leinen M (1993) Chemical transport to the seafloor of the equatorial Pacific Ocean across a latitudinal transect at $135^{\circ} \mathrm{W}$ : Tracking sedimentary major, trace, and rare earth element fluxes at the Equator and the Intertropical Convergence Zone. Geochim Cosmochim Acta 57:4141-4163. https://doi.org/10.1016/0016-7037(93)90312-K

Nakada R, Ogawa K, Suzuki N, Takahashi S, Takahashi Y (2014) Late Triassic compositional changes of aeolian dusts in the pelagic Panthalassa: Response to the continental climatic change. Palaeogeogr Palaeoclimatol Palaeoecol 393:61-75. https://doi.org/10.1016/j.palaeo.2013.10.014

Nelson DM, Tréguer P, Brzezinski MA, Leynaert A, Quéguiner B (1995) Production and dissolution of biogenic silica in the ocean: Revised global estimates, comparison with regional data and relationship to biogenic sedimentation. Glob Biogeochem Cycles 9:359-372. https://doi.org/10.1029/95GB01070

Nesbitt HW, Young GM (1982) Early Proterozoic climates and plate motions inferred form major element chemistry of lutites. Nature 299:715-717. https://doi.org/10.1038/299715a0

Nordt L, Atchley S, Dworkin S (2015) Collapse of the Late Triassic megamonsoon in western equatorial Pangea, present-day American Southwest. Geol Soc Am Bull 127:1798-1815. https://doi.org/10.1130/b31186.1

Nozaki T, Nikaido T, Onoue T, Takaya Y, Sato K, Kimura J-I, Chang Q, Yamashita D, Sato H, Suzuki K, Kato Y, Matsuoka A (2019) Triassic marine Os isotope record from a pelagic chert succession, Sakahogi section, Mino Belt, southwest Japan. J Asian Earth Sci: X 1:100004. https://doi.org/10.1016/j.jaesx.2018. 100004
Nürnberg CC, Bohrmann G, Schlüter M, Frank M (1997) Barium accumulation in the Atlantic sector of the Southern Ocean: Results From 190,000-year records. Paleoceanogr 12:594-603. https://doi.org/10.1029/97PA01130

Ogg JG (2012) Triassic. In: Gradstein FM, Ogg JG, Schmitz MD, Ogg GM (eds) The Geologic Time Scale 2012 vol 2. Elsevier, pp 681-730. https://www. sciencedirect.com/science/article/pii/B9780444594259000251

Onoue T, Sato H, Nakamura T, Noguchi T, Hidaka Y, Shirai N, Ebihara M, Osawa T, Hatsukawa Y, Toh Y, Koizumi M, Harada H, Orchard MJ, Nedachi M (2012) Deep-sea record of impact apparently unrelated to mass extinction in the Late Triassic. Proc Natl Acad Sci USA 109:19134-19139. https://doi.org/10. 1073/pnas.1209486109

Onoue T, Sato H, Yamashita D, Ikehara M, Yasukawa K, Fujinaga K, Kato Y, Matsuoka A (2016a) Bolide impact triggered the Late Triassic extinction event in equatorial Panthalassa. Sci Rep 6:29609. https://doi.org/10.1038/srep29609

Onoue T, Zonneveld J-P, Orchard MJ, Yamashita M, Yamashita K, Sato H, Kusaka S (2016b) Paleoenvironmental changes across the Carnian/Norian boundary in the Black Bear Ridge section, British Columbia, Canada. Palaeogeogr Palaeoclimatol Palaeoecol 441:721-733. https://doi.org/10.1016/j.palaeo.2015. 10.008

Pfänder JA, Münker C, Stracke A, Mezger K (2007) Nb/Ta and Zr/Hf in ocean island basalts-Implications for crust-mantle differentiation and the fate of Niobium. Earth Planet Sci Lett 254:158-172. https://doi.org/10.1016/j.epsl.2006.11.027

Plank T, Langmuir CH (1998) The chemical composition of subducting sediment and its consequences for the crust and mantle. Chem Geol 145:325-394. https://doi.org/10.1016/S0009-2541(97)00150-2

Price JR, Velbel MA (2003) Chemical weathering indices applied to weathering profiles developed on heterogeneous felsic metamorphic parent rocks. Chem Geol 202:397-416. https://doi.org/10.1016/j.chemgeo.2002.11.001

Prochnow SJ, Nordt LC, Atchley SC, Hudec MR (2006) Multi-proxy paleosol evidence for middle and late Triassic climate trends in eastern Utah. Palaeogeogr Palaeoclimatol Palaeoecol 232:53-72. https://doi.org/10.1016/j. palaeo.2005.08.011

Racki G, Cordey F (2000) Radiolarian palaeoecology and radiolarites: is the present the key to the past? Earth Sci Rev 52:83-120. https://doi.org/10.1016/ S0012-8252(00)00024-6

Raqueneau O, Tréguer P, Leynaert A, Anderson RF, Brzezinski MA, DeMaster DJ, Dugdale RC, Dymond J, Fischer G, François R, Heinze C, Maier-Reimer E, Martin-Jézéquel V, Nelson DM, Quéguiner B (2000) A review of the Si cycle in the modern ocean: recent progress and missing gaps in the application of biogenic opal as a paleoproductivity proxy. Glob Planet Change 26:317-365. https://doi.org/10.1016/S0921-8181(00)00052-7

Ramezani J, Fastovsky DE, Bowring SA (2014) Revised chronostratigraphy of the Lower Chinle Formation strata in Arizona and New Mexico (USA): Highprecision U-Pb geochronological constraints on the Late Triassic evolution of dinosaurs. Am J Sci 314:981-1008. https://doi.org/10.2475/06.2014.01

Ramezani J, Hoke GD, Fastovsky DE, Bowring SA, Therrien F, Dworkin SI, Atchley SC, Nordt LC (2011) High-precision U-Pb zircon geochronology of the Late Triassic Chinle Formation, Petrified Forest National Park (Arizona, USA): Temporal constraints on the early evolution of dinosaurs. Geol Soc Am Bull 123:2142-2159. https://doi.org/10.1130/B30433.1

Reynard B, Lécuyer C, Grandjean P (1999) Crystal-chemical controls on rare-earth element concentrations in fossil biogenic apatites and implications for paleoenvironmental reconstructions. Chem Geol 155:233-241. https://doi. org/10.1016/S0009-2541(98)00169-7

Rigo M, Joachimski MM (2010) Palaeoecology of Late Triassic conodonts: Constraints from oxygen isotopes in biogenic apatite. Acta Palaeontol Pol 55: 471-478. https://doi.org/10.4202/app.2009.0100

Rigo M, Trotter JA, Preto N, Williams IS (2012) Oxygen isotopic evidence for Late Triassic monsoonal upwelling in the northwestern Tethys. Geology 40:515518. https://doi.org/10.1130/G32792.1

Rudnick RL, Gao S (2014) Composition of the continental crust. In: Holland HD, Turekian KK (eds) Treatise on Geochemistry, vol 4, 2nd edn. Elsevier, Oxford, pp 1-51

Sadiq M (1988) Thermodynamic solubility relationships of inorganic vanadium in the marine environment. Mar Chem 23:87-96. https://doi.org/10.1016/03044203(88)90024-2

Sato H, Onoue T, Nozaki T, Suzuki K (2013) Osmium isotope evidence for a large Late Triassic impact event. Nat Commun 4:2455. https://doi.org/10.1038/ ncomms 3455

Sato H, Shirai N, Ebihara M, Onoue T, Kiyokawa S (2016) Sedimentary PGE signatures in the Late Triassic ejecta deposits from Japan: Implications for the 
identification of impactor. Palaeogeogr Palaeoclimatol Palaeoecol 442:36-47. https://doi.org/10.1016/j.palaeo.2015.11.015

Schroeder JO, Murray RW, Leinen M, Pflaum RC, Janecek TR (1997) Barium in equatorial Pacific carbonate sediment: Terrigenous, oxide, and biogenic associations. Paleoceanogr 12:125-146. https://doi.org/10.1029/96PA02736

Sephton MA, Amor K, Franchi IA, Wignall PB, Newton R, Zonneveld JP (2002) Carbon and nitrogen isotope disturbances and an end-Norian (Late Triassic) extinction event. Geology 30:1119-1122. https://doi.org/10.1130/00917613(2002)0301119:CANIDA2.0.CO;2

Sholkovitz ER, Landing WM, Lewis BL (1994) Ocean particle chemistry: the fractionation of rare earth elements between suspended particles and seawater. Geochim Cosmochim Acta 58:1567-1579. https://doi.org/10.1016/ 0016-7037(94)90559-2

Sholkovitz ER, Shaw TJ, Schneider DL (1992) The geochemistry of rare earth elements in the seasonally anoxic water column and porewaters of Chesapeake Bay. Geochim Cosmochim Acta 56:3389-3402. https://doi.org/10. 1016/0016-7037(92)90386-W

Soda K, Onoue T (2019) Multivariate analysis of geochemical compositions of bedded chert during the Middle Triassic (Anisian) oceanic anoxic events in the Panthalassic Ocean. Geochem J 53:91-102. https://doi.org/10.2343/ geochemi.2.0540

Sugiyama K (1997) Triassic and Lower Jurassic radiolarian biostratigraphy in the siliceous claystone and bedded chert units of the southeastern Mino Terrane, Central Japan. Bull Mizunami Fossil Mus 24:79-193

Tada R (1991) Compaction and cementation in siliceous rocks and their possible effect on bedding enhancement. In: Einsele G, Ricken W, Seilacher A (eds) Cycles and Events in Stratigraphy. Springer-Verlag, Berlin

Takeno N (2005) Atlas of Eh-pH diagrams. Intercomparison of thermodynamic databases, Geological Survey of Japan Open File Report No.419

Takiguchi T, Sugitani K, Yamamoto K, Suzuki K (2006) Biogeochemical signatures preserved in ancient siliceous sediments; new perspectives to Triassic radiolarian bedded chert compositions. Geochem J 40:33-45. https://doi.org/ 10.2343/geochemj.40.33

Tanaka K, Watanabe N (2015) Size distribution of alkali elements in riverbed sediment and its relevance to fractionation of alkali elements during chemical weathering. Chem Geol 411:12-18. https://doi.org/10.1016/j. chemgeo.2015.05.025

Taylor SR, McLennan SM (1985) The continental crust: its composition and evolution. Blackwell, Oxford

Toyoda K, Tokonami M (1990) Diffusion of rare-earth elements in fish teeth from deep-sea sediments. Nature 345:607-609. https://doi.org/10.1038/345607a0

Tribovillard N, Algeo TJ, Lyons T, Riboulleau A (2006) Trace metals as paleoredox and paleoproductivity proxies: An update. Chem Geol 232:12-32. https://doi. org/10.1016/j.chemgeo.2006.02.012

Trotter JA, Williams IS, Nicora A, Mazza M, Rigo M (2015) Long-term cycles of Triassic climate change: a new $\delta^{18} \mathrm{O}$ record from conodont apatite. Earth Planet Sci Lett 415:165-174. https://doi.org/10.1016/j.epsl.2015.01.038

Uno K, Yamashita D, Onoue T, Uehara D (2015) Paleomagnetism of Triassic bedded chert from Japan for determining the age of an impact ejecta layer deposited on peri-equatorial latitudes of the paleo-Pacific Ocean: a preliminary analysis. Phys Earth Planet Int 249:59-67. https://doi.org/10.1016/j. pepi.2015.10.004

Van Bennekom AJ, Berger GW, Van der Gaast SJ, de Vries RTP (1988) Primary productivity and the silica cycle in the Southern Ocean (Atlantic sector). Palaeogeogr Palaeoclimatol Palaeoecol 67:19-30. https://doi.org/10.1016/ 0031-0182(88)90120-4

Wanty RB, Goldhaber MB (1992) Thermodynamics and kinetics of reactions involving vanadium in natural systems: Accumulation of vanadium in sedimentary rocks. Geochim Cosmochim Acta 56:1471-1483. https://doi.org/ 10.1016/0016-7037(92)90217-7

Wignall PB, Zonneveld JP, Newton RJ, Amor K, Sephton MA, Hartley S (2007) The end Triassic mass extinction record of Williston Lake, British Columbia. Palaeogeogr Palaeoclimatol Palaeoecol 253:385-406. https://doi.org/10.1016/ j.palaeo.2007.06.020

Yamashita D, Kato H, Onoue T, Suzuki N (2018) Integrated Upper Triassic Conodont and Radiolarian Biostratigraphies of the Panthalassa Ocean. Paleontol Res 22:167-197. https://doi.org/10.2517/2017PR020

Yao A, Matsuda T, Isozaki Y (1980) Triassic and Jurassic radiolarians from the Inuyama area, central Japan. J Geosci Osaka City Univ 23:135-154
Yasukawa K, Liu H, Fujinaga K, Machida S, Haraguchi S, Ishii T, Nakamura K, Kato Y (2014) Geochemistry and mineralogy of REY-rich mud in the eastern Indian Ocean. J Asian Earth Sci 93:25-36. https://doi.org/10.1016/j.jseaes.2014.07.005

Zachos JC, Arthur MA, Dean WE (1989) Geochemical evidence for suppression of pelagic marine productivity at the Cretaceous/Tertiary boundary. Nature 337: 61-64. https://doi.org/10.1038/337061a0

\section{Publisher's Note}

Springer Nature remains neutral with regard to jurisdictional claims in published maps and institutional affiliations.

\section{Submit your manuscript to a SpringerOpen ${ }^{\circ}$ journal and benefit from:}

- Convenient online submission

- Rigorous peer review

- Open access: articles freely available online

High visibility within the field

- Retaining the copyright to your article

Submit your next manuscript at $\boldsymbol{\nabla}$ springeropen.com 